\title{
Expanding an existing classification of New Zealand vegetation to include non-forested vegetation
}

\author{
Susan K. Wiser ${ }^{1 * \dagger}$, Fiona J. Thomson ${ }^{1 \dagger}$ and Miquel De Cáceres ${ }^{2,3}$ \\ ${ }^{1}$ Landcare Research, PO Box 69040, Lincoln 7640, New Zealand \\ ${ }^{2}$ CEMFOR-CTFC, Crta de St Llorenç de Morunys, Km.2, Solsona 25280, Spain \\ ${ }^{3}$ CREAF, Cerdanyola del Vallès 08193, Spain \\ *Author for correspondence (Email: wisers@landcareresearch.co.nz) \\ ${ }^{\dagger}$ These authors contributed equally
}

Published online: 25 October 2015

\begin{abstract}
We produced the first national-scale quantitative classification of non-forest vegetation types, including shrubland, based on vegetation plot data from the National Vegetation Survey Databank. Semisupervised clustering with the fuzzy classification algorithm Noise Clustering was used to incorporate these new data into a pre-existing quantitative classification of New Zealand's woody vegetation. Fuzzy classification allows plots to be designated as transitional when they are similar to multiple vegetation types; the Noise Clustering algorithm allows plots having unique composition to be designated as outliers. We combined plot data collected using two different methods by transforming abundances to relative ranks and showed our classification results were robust to this. Of the 6362 plots analysed, 505 were assigned to previously defined woody vegetation types. Using the remaining 5857 plots, we defined vegetation types at two hierarchical levels comprising 25 alliances and 56 associations. Ten of the alliances are tussocklands, six are grasslands, four are stonefields or gravelfields, two are herbfields, one is rushland, and two are newly defined woody alliances. The classification defined compositional differences among well-known widely distributed short and tall tussock grasslands of the South Island. Notably it distinguished Chionochloa pallens, C. crassiuscula and C. oreophila tussocklands in wetter western regions from those dominated by C. rigida and C. macra in the east, and the domination of eastern South Island short tussock grasslands by Festuca novae-zelandiae and Poa colensoi. We demonstrate the distinctiveness of the vegetation of four naturally uncommon ecosystems - coastal turfs, northern gumlands, granite sand plains and braided riverbeds. Insufficient plot data precluded the definition of North Island Chionochloa rubra grassland types and many wetland and coastal communities. The 1846 plots designated as outliers mainly occur on warmer, wetter and less invaded sites than classified plots. Semi-supervised clustering allowed us to progress the development of an extendable, plot-based, quantitative classification of all New Zealand's vegetation despite data gaps.
\end{abstract}

Keywords: alpine; braided riverbed; coastal turf; fuzzy classification; grasslands; Noise Clustering; semisupervised classification; tussock grasslands; vegetation-plot database; vegetation types; wetlands

\section{Introduction}

Classification of vegetation is essential to simplify the diversity of plant species assemblages on the landscape into meaningful units. As such, classification provides an important tool for describing and understanding this component of biodiversity and for underpinning biodiversity reporting, and management (reviewed by Faber-Langendoen et al. 2014). Although a quantitative national-scale classification of New Zealand's woody vegetation types based on vegetation plot data has been produced (Wiser et al. 2011; Wiser \& De Cáceres 2013), there has been no parallel effort for the remaining non-forested vegetation types.

New Zealand non-forest vegetation ranges from alpine tussock grasslands dominated by Chionochloa species to exotic-dominated grasslands at lower elevations (Cockayne 1928; Wardle 1991; Mark 1993; Mark \& McLennan 2005) to low-statured types of unusual environments such as coastal turfs and alpine granite gravel fields (Williams et al. 2007; Rogers \& Wiser 2010; Richardson et al. 2012). At the New Zealand scale, classifications of non-forest vegetation have been broad and non-formalised, focusing on readily recognised physiognomic (e.g. tall tussock vs short tussock grasslands) or geographic features (Wardle 1991; Mark \& McLennan 2005) or have been based on qualitative, literature-based interpretations (Singers \& Rogers 2014). Aerial photography and satellite imagery have allowed broad vegetation or landcover classes to be mapped at a coarse resolution (e.g. Vegetation Cover Map by Newsome (1987), Land Cover Database 3 by Newsome $\&$ Pairman (2012)). In other countries, vegetation classification standards usually require vegetation types to be based on plant compositional data collected from vegetation plots (e.g. Jennings et al. 2009). As such, data are required to adequately describe the types and allow new plots to be ascribed to them. In defining vegetation types from plot data, quantitative classifications, i.e. those applying a numerical classification algorithm to a set of vegetation plot records, have the advantage over expert-based classifications of allowing the delineation of vegetation types to be done in a formalised, repeatable way (Mucina 1997) and are the only practicable option for very large, complex datasets. Vegetation types that have been quantitatively derived are given the highest confidence ranking 
in national vegetation classification systems (e.g Jennings et al. 2009; Silvertsen 2009). In New Zealand, numerous expert and quantitative plot-based classifications have been produced for given regions or within particular non-forest vegetation types (e.g. Connor 1965; Scott 1977; Rose \& Platt 1987; Duncan et al. 1990; Wilson 1976, 1987; Wiser \& Buxton 2009; Rogers \& Wiser 2010; Woolmore 2011).

For woody vegetation in New Zealand, three factors facilitated the development of a national quantitative plotbased classification. The first was the establishment in 2002-2007 of consistently measured plots at intersections of an 8-km grid superimposed on mapped forests and shrublands. This nationally representative dataset allowed broad-scale classification to be conducted, although it lacked sufficient sampling resolution to define rare types (Wiser et al. 2011). The second beneficial aspect of vegetation sampling was the widespread adoption since the early 1970s of the 'Recce' method (Allen 1992; Hurst \& Allen 2007) when assessing forest composition. Here, the primary measure is species percentage cover in height strata using predefined cover classes. Data from disparate projects were incorporated into the classification of Wiser et al. (2011) to begin a description of less common woody vegetation types and to increase the typological resolution of the classification (Wiser \& De Cáceres 2013). The third factor was that much of the forest compositional data are readily available from the National Vegetation Survey Databank (Wiser et al. 2001).

Construction of a parallel classification of non-forest vegetation in New Zealand is challenged by the more pronounced compositional heterogeneity, and more limited and inconsistent sampling and data storage. Standard methods have been proposed and sometimes adopted for measuring grassland vegetation (see review in Wiser \& Rose 1997), but no single method has been implemented across New Zealand. This has resulted in different abundance values being collected, including species percentage cover or ranks (based on cover) within plots or species frequencies along transects. Additionally, there are strong geographic and biotic biases in which non-forest vegetation types have been sampled using plots. In other instances, compositional data exist but either consist of species lists only, which may not be complete (e.g. nationwide surveys of sand dunes; Johnson 1992; Partridge 1992) or were collected using a site-specific method (e.g. Cockayne \& Calder 1932; Mark 1978; Walker \& Lee 2002; Williams \& Wiser 2004; Wiser et al. 2010).

Traditionally, quantitative vegetation classifications have been static; when new data are incorporated the original classification data must be reanalysed, which destroys the original hierarchy and classes themselves (De Cáceres et al. 2010; De Cáceres \& Wiser 2012). As such, one would be reluctant to develop a quantitatively based national classification until there was comprehensive coverage of vegetation plot data (the term 'plot' is used here in a broad sense to incorporate both quadrat and transect data) collected in a consistent way. A framework has recently been developed, termed 'semisupervised clustering' (Tichý et al. 2014), that allows new data to be incorporated into a pre-existing classification, while retaining types defined in the original classification (De Cáceres et al. 2010). For New Zealand's woody vegetation, adopting this framework allowed the 17 vegetation alliances described by Wiser et al. (2011) to be retained and also related to a finer thematic level when new data were analysed, and 12 new alliances and 79 associations to be defined (Wiser \& De Cáceres 2013; the names 'alliance' and 'association' follow usage in Europe and North America; Peet \& Roberts 2013). Adopting this framework allows us to initiate the development of a plot-based, quantitative classification of New Zealand's non-forest vegetation despite data not being comprehensive.

Here, our primary aim is to produce the first national-scale quantitative classification of non-forest vegetation that can be defined using available plot data. To do this we extended the classification approach of Wiser and De Cáceres (2013) to allow datasets that use various measures of abundance to be incorporated. We provide detailed descriptions of defined nonforest vegetation types at two levels of typological resolution. We also explicitly compare the classification consequences of combining plots collected using two species performance scales (species frequency on transects vs species percentage cover) and ask: (1) where data have been collected from the same location using more than one abundance scale, does the choice of species abundance scale influence the classification of a plot to a vegetation type? Then, we examine compositional and geographic gaps in the classification. We ask: (2) do plots designated as outliers primarily sample the unstructured compositional patterns observed in successional, exoticdominated vegetation of lower elevation, dryer and warmer locations (e.g. Moore et al. 1976; Hubbard \& Wilson 1988; Wilson et al. 1989), as found for woody vegetation by Wiser and De Cáceres (2013); and (3) what are the geographic and compositional gaps in readily available non-forest vegetation data?

\section{Methods}

\section{Classification scope and data sources}

The scope of a classification can be defined by its spatial, temporal and ecological (i.e. thematic) extents (De Cáceres et al. 2015). Here, the spatial extent includes New Zealand's North Island, South Island and Stewart Island, but excludes large offshore islands such as Great Barrier, Three Kings, Raoul and the Chatham Islands. The temporal extent includes any vegetation measurements from 1970 onwards. The thematic extent includes records of vascular plants in non-forested vegetation, including shrublands that were not previously defined in the classifications of woody vegetation of Wiser et al. (2011) or Wiser and De Cáceres (2013).

Plot data were sourced from the National Vegetation Survey Databank (Wiser et al. 2001). Given the defined scope, further criteria for plot records to be included in the dataset were the following: (a) abundance values were recorded for all vascular plant species in a plot; (b) for permanent plots only, the most recent measurement was used; (c) plots were not associated with exclosures or other experimental treatments; and (d) plot records must have geographic coordinates. In total we collated 6362 putative 'non-forest' plot records.

\section{Data standardisation and transformation}

The majority of data were collected using one of four different survey methods: (1) The frequency of each species was recorded using fifty $15-\mathrm{cm}$-diameter $\left(0.07 \mathrm{~m}^{2}\right)$ circular subplots centred at $40-\mathrm{cm}$ intervals along a $20-\mathrm{m}$ transect, a method introduced by the former New Zealand Forest Service (Wiser \& Rose 1997); (2) The frequency of each species was recorded using fifty $0.25-\mathrm{m}^{2}$ quadrats centred at $2-\mathrm{m}$ intervals along a $100-$ $\mathrm{m}$ transect, a method introduced by the former Department of Lands and Survey (Duncan et al. 2001); (3) Species were 
ranked on the basis of their dominance (i.e. from most abundant to least abundant; Wilson 1976, 1987); or (4) The abundance of each species was recorded in seven fixed-height tiers using a modified Braun-Blanquet cover-abundance scale, the "Recce" method (Hurst \& Allen 2007). For the last method, a cumulative cover value was generated for each species on each plot by converting its cover score within each height tier to the midpoint of the percentage cover range for that coverabundance class, and summing these values across tiers (e.g. Wiser et al. 2002, 2011). To retain the differences in dominance of different species recorded on a plot or transect but create a consistent abundance measure across the different methods, we converted the plot-level abundance values to absolute ranks. Species were ranked from $1=$ the least abundant to $n$ $=$ the most abundant species on a plot or transect (where $n$ is equivalent to the total number of species on the plot). Such ordering was required because our distance measure is based on abundance values (see below), and assumes that higher values represent more abundant species. Species with the same abundance measures on a plot or transect were assigned an equal, average rank.

Constructing a taxonomically homogeneous dataset can be challenging, especially when multiple datasets of mixed provenance are combined (Peet \& Roberts 2013). First, we deleted records of any taxa not resolved at least to the genus level, following Peet and Roberts (2013). Peet and Roberts (2013) also recommend deleting any plots with 'many' taxa not identified to the species level; accordingly we deleted all plots where $>25 \%$ of the taxa were identified to genus only. Owing to the known inconsistencies around recording taxonomic levels below species, we aggregated all subspecies and varieties to the species level. Most problematic was when within a specific genus there was a mixture of observations identified to species level and genus level within the final aggregated dataset. For genera where more than $30 \%$ of the records were at the genus level, we aggregated all specieslevel records to the genus level. For genera where fewer than $30 \%$ of the records were at the genus level, we deleted these lower-resolution records.

We addressed the issue of taxonomic changes in species names following the approach of Wiser and De Cáceres (2013); that is, homotypic synonyms were identified and the current name was applied (based upon Ngā Tipu o Aotearoa, the New Zealand Plants database http://nzflora.landcareresearch. co.nz/, as of August 2013) and, where we were aware of different concepts being signified by a name, we associated the broadest taxonomic concept with that name and aggregated records accordingly.

\section{Noise Clustering}

Our approach to semi-supervised clustering was based upon a fuzzy classification algorithm called Noise Clustering (Dave 1991; De Cáceres et al. 2010; Wiser \& De Cáceres 2013). The use of fuzzy classification explicitly addresses the understanding that vegetation composition varies along a continuum. As opposed to hard clustering, where plot records belong to one and only one vegetation type, fuzzy clustering produces a membership value for each plot to each cluster, ranging from 0 to 1 . In so doing, plot records can be designated as transitional when they are similar (i.e. have high membership) to more than one cluster. Large values of the fuzziness coefficient, $m$, increase the number of transitional plots, whereas small values make the classification less fuzzy and more like a traditional hard partition. Additionally, the Noise Clustering algorithm allows plot records that are outliers in their vegetation composition to be recognised in a special class. The 'noise' class (hereafter termed 'outlier' class) captures plot records that are further than a specified distance from all the centroids of the 'true' clusters. The distance parameter, $\delta$, can be altered for the analysis, with different values changing the degree of typological resolution of the classification. For example, Wiser and De Cáceres (2013) defined two levels for their classification of New Zealand woody vegetation: for the finer resolution 'association'-level classification $\delta$ was set to a lower value than for the coarser resolution 'alliance'-level classification. Large values of $\delta$ will increase the number of plot records assigned to clusters, making clusters more heterogeneous, whereas small values of $\delta$ will increase the number of plot records assigned to the outlier class. The distance parameter $\delta$ can also influence the number of 'transitional' plots. Plot records in the outlier class represent compositional combinations that have not been sampled frequently enough to allow a vegetation type to be defined (note that we use the term 'vegetation type' throughout this paper when the reference is generic and can apply to either alliance or association level). Noise Clustering is thus a conservative approach to defining vegetation types. Leaving plot data unclassified rather than assigning a plot to a type to which its composition only weakly corresponds and allowing plots to be designated as transitional ensure that defined vegetation types are relatively homogeneous and robustly defined. Plots in the outlier class may be assigned a posteriori to the existing types by relaxing the value of $\delta$ or they may become part of new clusters once more data become available.

\section{Exclusion of previously-defined woody vegetation plots}

Our first goal was to determine whether any of the plots in our 6362-plot dataset conformed to any of the woody alliances or associations that we had previously defined. We did this in two stages. The classification of Wiser and De Cáceres (2013) was underpinned by Recce data only. We assigned the subset of plots in our dataset that had Recce data (2725 plots) to the previously-defined woody alliances and associations, using the Noise Clustering membership function with $m$ set to 1.1 and $\delta$ set to 0.83 and 0.75 for alliances and associations, respectively, to retain consistency with Wiser \& De Cáceres (2013). A total of 178 plots were assigned to either a woody alliance or association. This left 2547 plots with Recce data unassigned, i.e. assigned to the outlier class.

To perform the corresponding analysis on plots where abundance had been recorded using a different method, we not only had to convert abundance to absolute ranks as described earlier, but also had to recalculate the values for the centroids of the pre-existing classification of woody vegetation in rank space. To do this, we converted the abundance values of the community data matrix underpinning the woody classification to absolute ranks and calculated resemblance between plots, using the Chord distance (Orlóci 1967). The Chord distance calculates Euclidean distance after relativising species abundance on a plot by the total abundance of all species on the plot, thus decreasing the impact of plot richness on the abundance value. An alternative would be to use a distance measure specifically designed for ordinal data (Podani 2005), but this would be inconsistent with the approach of Wiser \& De Cáceres (2013) and computationally more demanding. We recalculated the positions of the fixed centroids for each alliance and association in rank space. We determined the value 
of $\delta$ that minimised the distance in membership between the same plots in the classifications determined from summed cover abundances versus those determined from ranks. In rank space, the best $\delta$ values were 0.84 at the alliance level and 0.76 at the association level. We then assigned 6190 plot records with abundance designated by ranks to the woody alliances. For completeness, we included those percentagecover plots that remained unassigned in the previous step, but now their abundance values were converted to absolute ranks. Of these, 332 plots were assigned to either a woody alliance or association. The remaining 5857 plot records were considered to represent bona fide vegetation types that were not previously defined in the woody classification. The 244 datasets and the number of plots sourced from each are provided in Appendix $\mathrm{S} 1$ in Supplementary Material.

\section{Evaluating whether species abundance scale influences how plots are classified}

To evaluate the consequences of using ranks as a species abundance measure we ran two classification analyses using 121 plot records from the Waitaki Basin (Jane 1988) where both frequency (method 1 above) and percentage cover (method 4) data were collected. In the first instance, we calculated absolute ranks from frequency values, whereas in the second, absolute ranks were calculated from cover values. We set $\delta$ to 0.84 and $m$ to 1.1 , as before, and defined 1 to 20 new clusters using Noise Clustering. We decided on the number of clusters recognised to ensure a minimum of 20 plots in each. Fuzzy and hard membership values were calculated for each plot, and plots were assigned to clusters following the criteria described above. We then compared the assignment of each plot by the two analyses. Frequent differences between the two analyses in the assignment of plot records would signify that classification results are strongly sensitive to differences in the original abundance measure. Moreover, we expected that each class should be composed equally of plots from both species abundance scales (i.e. a 50:50 ratio), reflecting the lack of bias in class membership induced by the species abundance scale. Departure from this ratio would signify classification bias due to the original species abundance measure. To test this we conducted a two-sided test of proportions (Newcombe 1998).

\section{Cluster analyses}

In an analogous process to that used by Wiser and De Cáceres (2013), we extended the woody classification to the 5857-plot record matrix. We ran Noise Clustering iteratively, with each iteration having the 29 original woody alliances plus $n$ new alliances, where $n=1$ to 50 clusters using $\delta=0.84$ and $m=$ 1.1. In all cluster analyses, the 29 centroids of the previously defined woody alliances were used as fixed elements so that the newly defined alliances would be as distinct from them as possible (De Cáceres et al. 2010). We repeated the same analyses at the association level using $\delta=0.76, m=1.1$ and the 79 centroids of the previously defined woody associations as fixed elements. In this analysis we defined $n=1$ to 80 new clusters representing new associations.

Plot records with fuzzy memberships equal to or greater than 0.5 in a given vegetation type were assigned that type. Plot records with fuzzy membership equal to or greater than 0.5 in the outlier class were so designated. Plot records with fuzzy membership less than 0.5 for all types, including the outlier class, were designated transitional. Associations were assigned to those alliances to which they had the highest membership, following Wiser \& De Cáceres (2013). Associations with fuzzy membership equal to or greater than 0.5 in the outlier alliance class were so designated.

To choose the appropriate number of new alliances and associations, we used the three criteria of Wiser and De Cáceres (2013). The first criterion was to maximise the number of plots having fuzzy membership $\geq 0.5$ to a vegetation alliance or association (thereby reducing the number of plot records in the outlier class or designated transitional). The second criterion was to minimise the number of poorly defined alliances (i.e. those with $\leq 20$ plot records and a cluster variance $>0.6$ ) or poorly defined associations (i.e. those with $\leq 10$ plot records and a cluster variance $>0.5$ ). The third criterion examined the relationship between alliances and associations. The first aim was to minimise the number of alliances with no component associations. The second aim was to minimise the number of associations having $\geq 20$ plot records and high $(>0.5)$ membership to the outlier class.

\section{Naming and characterising vegetation types}

Compositional names for alliances and associations were derived from those species having both the highest constancy (i.e. frequency within that alliance or association) and highest mean relativised rank (i.e. mean of the absolute rank values relativised by the sum of rank values in a plot) and follow the International Vegetation Classification naming conventions (Jennings et al. 2009). This convention is akin to that defined by Atkinson $(1962,1985)$, which has been widely applied to New Zealand vegetation. A maximum of four species were incorporated into alliance names and six into association names, with priority given to species in the taller tiers. Square brackets indicate those species with constancy values $<0.7$ (i.e. species that occurred in fewer than $70 \%$ of plots of that type). A backslash was used to indicate species occurring in different tiers. The compositional name is followed by the structural class name, according to Atkinson (1985). Note that the structural class name 'grassland' following Atkinson(1985) excludes the tussock grass growth form, as those ecosystems dominated by the latter growth form are termed 'tussocklands'.

When synthesising plot records of diverse provenance, a further challenge is the lack of consistent environmental and historical data about the sites to aid interpretation of the observed patterns. Across the datasets, the most consistently recorded site variables were geographic grid reference, elevation, aspect and slope; broad categories of drainage and landform were sometimes recorded. We used plot locations to derive values of climate variables (mean annual air temperature, minimum air temperature, mean annual rainfall, and October vapour pressure deficit) from GIS layers, following Leathwick et al. (2002). October vapour pressure deficit is a measure of evaporative demand in plants and is correlated to tree distributions in New Zealand (Leathwick \& Whitehead 2001). To characterise the environment of each vegetation type, we assessed the geographic and elevational range, calculated means and ranges for slope steepness, and examined box plots of slope aspect. We sourced biostatus from the New Zealand Plants database for all species and calculated the percentage of species on a plot that were exotic. It is also well known that land use, grazing, topography (particularly as it influences snow-lie in alpine areas), soil moisture, and soil fertility are major influences on grassland composition (see review by Mark 1993). We lack the data, however, to draw definitive conclusions about the degree to which the vegetation types we define reflect past and present land use and fine-grained environmental variation. 
To aid in description, we assigned plots to bioclimatic zones following Wardle (1991) and Meurk (1995), but here we clarify terminology. In New Zealand the term 'subalpine' has generally referred not only to the uppermost treeline forest (following international convention), but also to the tall tussock shrubland above. Wardle (1991) introduced the term 'penalpine' for the upslope margin of tall tussock shrubland because of the then generally held opinion that New Zealand treelines are lower and warmer during the growing season than those in comparable places overseas. 'Penalpine'was therefore regarded as equivalent to the higher reaches of 'subalpine' internationally. Recent research on treeline temperatures in New Zealand show they are as cold as elsewhere during the growing season (Mark et al. 2008; Cieraad \& McGlone 2014; Cieraad et al. 2014), and the vast majority of exotic treeline species will not flourish above the indigenous treeline. We therefore use 'low alpine' in place of 'penalpine' and our use of 'subalpine' is restricted to that elevational zone where forest, if it was present, would be above the limit of lianas and below the treeline. Our use of the terms 'cold temperate' and 'warm temperate' implies that these are oceanic, as articulated by McGlone et al.(2012). Using these conventions, our elevational zones, from low to high elevation are warm temperate, cool temperate, subalpine, low alpine, alpine and subnival.

\section{Do unclassified plots sample specific environments or unstructured vegetation?}

We used two analyses to determine whether plots that remained unclassified (i.e. those assigned to the outlier class) represented successional, exotic-dominated vegetation of lower elevation (dryer and warmer locations). First, we used a Wilcoxon rank-sum test to compare climate variables (mean annual air temperature, mean minimum air temperature of coldest month, mean annual solar radiation and October vapour pressure deficit) and percentage exotic for assigned (transitional also included) versus outlier plots across all datasets. Second, for datasets with $>20$ plots ( $n=45$ datasets; Appendix S1), we used generalised linear models to determine whether there were consistent differences in percentage exotic, elevation and species richness between assigned/transitional plots versus outlier plots within individual datasets.

All statistical analyses were carried out using the $\mathrm{R}$ statistical language (v. 3.02). The vegclust library (De Cáceres et al. 2010) was used for classification analyses.

\section{Results}

\section{Does species abundance scale influence how plots are classified?}

Six clusters were defined from the 121 Waitaki Basin plots having both percentage cover and frequency data. For $79 \%$ of these plots, data collection method did not change the cluster to which the plots were assigned (i.e. ranking of results from both methods (frequency and percentage cover) resulted in these plots being assigned to the same cluster). Plots assigned differently by the two methods generally had one assignment as transitional or outlier ( $73 \%$ of mismatched plots) rather than both assignments to different clusters (17\%). For those plots where one method classified them as transitional and the other assigned them to a cluster, both would be assigned to the same cluster if the maximum membership was used, rather than requiring membership to be $>0.5$. Vegetation types were not differentiated by species abundance scale: across all six clusters, the ratio of records with frequency data to those with percentage cover data did not significantly differ from an expected value of 50:50 $\left(\chi^{2}=1.958\right.$, d.f. $=6, P=0.92$, range 43:56-59:41).

\section{Cluster analysis}

Using the full plot dataset (5857 plots), we defined 25 new alliances and 56 new associations. This maximised the number of plots assigned to an alliance or association (Appendix S2 a, b) and resulted in no alliances or associations with high variance but low numbers of plots assigned (Appendix S2 c, d). This combination also meant that all alliances had a component association (Appendix S3 a), and minimised the number of associations (three) having high membership to the outlier class and $\geq 20$ plot records (Appendix S3 b). The percentage of plot records assigned to the outlier class was $32 \%$ at the alliance and $48 \%$ at the association level (Appendix S4). Eleven narrowly distributed alliances were defined from plots sampled using one method, whereas the other, more broadly distributed alliances were based on plots sampled using different sampling methods (Figs 1, 2 \& 3).

\section{Characterisation of alliances and associations}

Ten of the alliances defined are tussocklands, six are grasslands (sensu Atkinson (1985)), four are stonefields or gravelfields, two are herbfields, one is rushland, and two are newly defined woody alliances; incorporation of new data and non-Recce plots enabled one new shrubland and one new forest alliance to be defined (Table 1). Three alliances are widespread throughout New Zealand, two are restricted to the North Island, 19 are only found on the South Island, and one is found on both the South Island and Stewart Island (Figs $2 \& 3$ ). This reflects the much greater extent of grasslands in the South Island (Cockayne 1928; Wardle 1991; Mark 1993), but also the available plot data: $91 \%$ of the plot records are from the South Island, with the North Island and Stewart Island each having 4.5\%).

The order of presentation and higher level headings predominantly follow those used by Wardle (1991) to organise presentation of New Zealand plant communities, except that we present non-woody types first. For tussock grasslands, however, we follow the typology of Mark and McLennan (2005), but where appropriate we replace the use of the term 'montane' with the term 'cool temperate' to match the bioclimatic zones of Wardle (1991) and Meurk (1995) and alter the bioclimatic zones specified based on the environmental data of the plots themselves. Codes are assigned to each alliance and association by combining letters derived from the vegetation structural class with a number reflecting our presentation sequence. Species that are not sufficiently dominant to be included in the alliance or association name, but which occur in $\geq 75 \%$ of plots, are listed in order of descending constancy; to avoid repetition, those species listed in the name are not repeated in the descriptions. When exotic species comprise, on average, $\geq 5 \%$ of the species on a plot, this is noted. Where more than one association was assigned to an alliance, these associations and their differences are described. Associations that did not fit into a defined alliance are described at the end of the appropriate section. References to comparable vegetation types previously described in the literature use the published vegetation type names, regardless of whether these comprise scientific or vernacular plant names. A synoptic table listing all species having constancy $>0.6$ in any one alliance is provided in Appendix S5. 
T1 Chionochloa crassiuscula-Schoenus pauciflorus-Poa colensoi / Astelia linearis tussockland T2 Chionochloa pallens / Poa colensoi / Anisotome aromatica-Gaultheria depressa tussockland T4 Chionochloa pallens / Poa colensoi-Celmisia petriei-Schoenus pauciflorus / Wahl. alb. tussockland T5 Chionochloa rigida / Poa colensoi-Festuca novae-zelandiae / Hypochaeris radicata tussockland T6 Chionochloa macra-Poa colensoi / Celmisia lyallii-[Luzula rufa] grassland tussockland 17 Chionochloa rubra / Schoenus pauciflorus-Celmisia coriacea-Coprosma cheesemanii tussockland T8 Festuca novae-zelandiae-Anthoxanthum odoratum-Poa colensoi / Leucopogon fraseri tussockland 9 Festuca novae-zelandiae / Anthoxanthum odoratum-Trifolium repens-Hypochaeris radicata tussockland 10 Poa colensoi-Rytidosperma setifolium-Festuca matthewsii / Wahlenbergia albomarginata tussockland G1 Poa cita-Dactylis glomerata / Anthoxanthum odoratum-Trifolium repens grassland

G3 Cynosurus cristatus-Trifolium repens-Anthoxanthum odoratum-Hypochaeris radicata grassland G4 Lolium perenne-Holcus lanatus-Trifolium repens-Hypochaeris radicata grassland H1 Selliera radicans-Leptinella dioica-Samolus repens herbfield

G5 Agrostis capillaris-Carex sinclairii-Poa pratensis-Holcus lanatus grassland

R1 Empodisma minus-Gleichenia spp.-Baumea rubiginosa rushland

StF1 Poa lindsayi-Raoulia hookeri-Epilobium melanocaulon-Trifolium repens stonefield G6 Poa colensoi /Chionochloa oreophila-Celmisia sessiliflora-Celmisia haastii grassland GF1 Poa colensoi / Luzula pumila-Raoulia hectorii gravelfield GF2 Raoulia grandiflora-Veronica pulvinaris-Anisotome imbricata-Dracophyllum pronum gravelfield H2 Celmisia spectabilis-Poa colensoi/Anisotome aromatica-Euphrasia cuneata herbfield

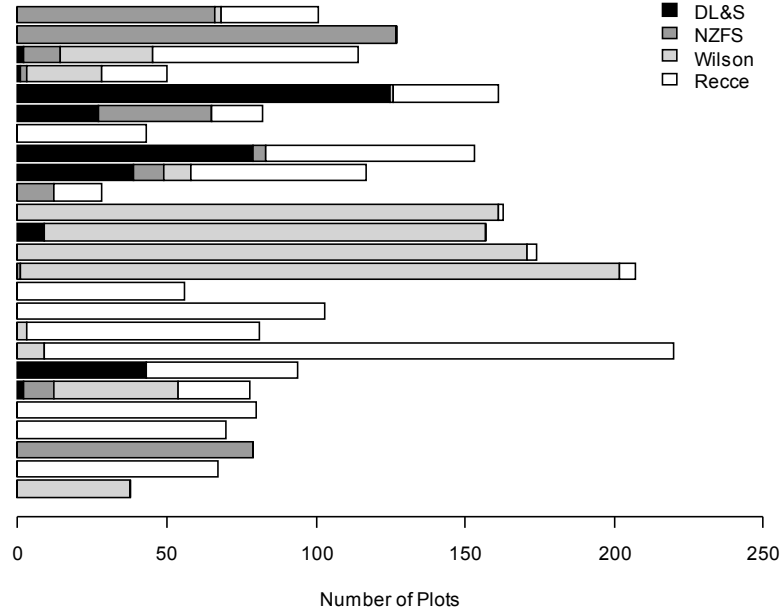

Figure 1. Number of plot records in each of the 25 alliances that use the four major vegetation survey method: New Zealand Forest Service transects (dark grey, NZFS), Department of Lands and Survey transects (black, DL\&S), "Recce" plots (white), and Wilson ranked species (light grey).

Table 1. Summary of non-forest alliances and component associations. Associations were assigned to the alliance (or outlier class) where they had the highest membership. The number of plots in each alliance or association is listed in parenthesis after the name. Order of associations within alliances matches order of presentation in the text. *Indicates that although the association has the highest membership to this alliance, it is transitional with either another alliance or the outlier class.

\begin{tabular}{llll}
\hline Alliance & Distribution & $\begin{array}{l}\text { Elevational } \\
\text { range }(\mathrm{m})\end{array}$ & $\begin{array}{l}\text { Mean } \\
\text { percentage } \\
\text { exotic }\end{array}$
\end{tabular}

\section{GRASSLAND AND HERBFIELD}

\section{Subalpine-subnival snow tussock}

[T1] Chionochloa crassiuscula-Schoenus pauciflorus-Poa colensoi/Astelia linearis tussockland (100)

[T2] Chionochloa pallens/Poa colensoi/ Anisotome aromatica-Gaultheria depressa tussockland (127)
[T3] Chionochloa pallens/Poa colensoi tussockland (114)

[T4] Chionochloa pallens/Poa colensoiCelmisia petriei-Schoenus pauciflorus/ Wahlenbergia albomarginata tussockland (50)

[T5] Chionochloa rigida/Poa colensoiFestuca novae-zelandiae/Hypochaeris radicata tussockland (159) -Celmisia lyallii-Chionochloa crassiuscula
SI, Stewart $\quad 700-1540 \quad 0 \%$

SI

$960-1620 \quad 1 \%$

SI

$1050-1910 \quad 2 \%$

SI

$990-1590 \quad 4 \%$

SI

$710-1670 \quad 19 \%$
[T6] Chionochloa macra-Poa colensoi/Celmisia SI lyallii-[Luzula rufa] tussockland (82)
$1190-1950 \quad 8 \%$

$1010-1450 \quad 7 \%$
*[T1.a1] Chionochloa crassiuscula-Schoenus pauciflorus/ Astelia linearis-Coprosma perpusilla tussockland (37)

*[T2.a1] Chionochloa pallens/Celmisia spectabilis-Poa colensoi/Chionochloa australis-Anisotome aromatica tussockland (25)

*[T2.a2] Chionochloa pallens/Chionochloa crassiusculaPoa colensoi-Anisotome aromatica-Gaultheria depressa tussockland (10)

*[T2.a3] Chionochloa pallens/Poa colensoi/Anisotome aromatica-Coprosma cheesemanii-Coprosma perpusillaGaultheria depressa - tussockland (23)

[T2.a4] Chionochloa pallens/Poa colensoi/Anisotome aromatica-Gaultheria depressa-Celmisia sessiliflora tussockland (31)

[T3.a1] Chionochloa pallens/Chionochloa crassiusculaPoa colensoi-Celmisia lyallii tussockland (56)

*[T3.a2] Chionochloa pallens/Poa colensoi-Celmisia lyallii-Schoenus pauciflorus tussockland (16)

*[T4.a1] Poa colensoi-Celmisia petriei-Schoenus pauciflorus/Anaphalioides bellidioides-Lycopodium fastigiatum-Coprosma perpusilla grassland (27)

[T5.a1] Chionochloa rigida/Festuca novae-zelandiaeAciphylla aurea-Poa colensoi-Pilosella officinarum tussockland (51)

[T5.a2] Chionochloa rigida/Poa colensoi-Hypochaeris radicata-Viola cunninghamii-Raoulia subsericea tussockland (61)

*[T5.a3] Poa colensoi-Agrostis muelleriana-Luzula rufaViola cunninghamii grassland (27)

[T6.a1] Chionochloa macra-Poa colensoi/Celmisia lyallii-Anisotome aromatica tussockland (41)

Cool temperate-low alpine tall red/copper tussock [T7] Chionochloa rubra/Schoenus pauciflorus- SI Celmisia coriacea-Coprosma cheesemanii tussockland (43)
[T7.a1] Chionochloa rubra/Schoenus pauciflorusCelmisia coriacea-Microseris scapigera-Coprosma cheesemanii tussockland (29) 


\begin{tabular}{lll}
\hline Alliance & Distribution & $\begin{array}{l}\text { Elevational } \\
\text { range }(\mathrm{m})\end{array}$ \\
\end{tabular}

No corresponding alliance

Mean
percentage
exotic

45\% [T.a1] Chionochloa rubra/Schoenus panciflorus-Holcus lanatus-Anthoxanthum odoratum tussockland association (19)

Cool temperate-low alpine short tussock

[T8] Festuca novae-zelandiae-Anthoxanthum odoratum-Poa colensoi/Leucopogon fraseri tussockland (150)

[T9] Festuca novae-zelandiae/ Anthoxanthum odoratum-Trifolium repensHypochaeris radicata grassland (116)

[T10] Poa colensoi-Rytidosperma setifoliumFestuca matthewsii/Wahlenbergia albomarginata tussockland (25)

\section{Adventive-dominated grasslands}

[G1] Poa cita-Dactylis glomerata/ Anthoxanthum odoratum-Trifolium repens grassland (162)

[G2] Lolium perenne-Bromus hordeaceusVulpia bromoides-Trifolium glomeratum grassland (157)

[G3] Cynosurus cristatus-Trifolium repensAnthoxanthum odoratum-Hypochaeris radicata grassland (169)

[G4] Lolium perenne-Holcus lanatus-Trifolium repens-Hypochaeris radicata grassland (207)

No corresponding alliance

\section{Wetlands}

[G5] Agrostis capillaris-Carex sinclairii-Poa pratensis-Holcus lanatus grassland (103)
Eutrophic swamps and marshes
*[T8.a1] Festuca novae-zelandiae-Hypochaeris radicataWahlenbergia albomarginata-Rumex acetosellaRytidosperma setifolium-Poa colensoi tussockland (25) *[T8.a2] Festuca novae-zelandiae/Leucopogon fraseriAnthoxanthum odoratum-Hypochaeris radicataWahlenbergia albomarginata-Poa colensoi tussockland (32) *[T8.a3] Festuca novae-zelandiae-Anthoxanthum odoratum/Pilosella officinarum tussockland (25) [T8.a4] Festuca novae-zelandiae/Poa colensoi-Luzula rufa/Raoulia subsericea-Rumex acetosella-Pilosella officinarum tussockland (53)

[T8.a5] Festuca novae-zelandiae/Poa colensoiHypochaeris radicata-Raoulia subulata-Pilosella officinarium tussockland (41)

*[T9.a1] Agrostis capillaris-Anthoxanthum odoratum Festuca rubra-Trifolium repens grassland (36)

*[T9.a2] Festuca novae-zelandiae-Anthoxanthum odoratum-Hypochaeris radicata-Trifolium repens-Rumex acetosella grassland (30)

[T9.a3] Festuca novae-zelandiae-Poa cita/Anthoxanthum odoratum-Hypochaeris radicata-Acaena caesiglauca grassland (39)

*[T10.a1] Chionochloa rigida/Poa colensoiAnthoxanthum odoratum-Festuca matthewsii-Pilosella piloselloides-Hypochaeris radicata tussockland (34)

[G1.a1] Poa cita-Dactylis glomerata/Anthoxanthum odoratum-Holcus lanatus-Trifolium repens-Hypochaeris radicata grassland (108)

[G2.a1] Poa cita/Lolium perenne-Vulpia bromoidesDactylis glomerata-Bromus hordeaceus-Trifolium glomeratum grassland (72)

[G2.a2] Lolium perenne-Bromus hordeaceusHypochaeris radicata grassland (45)

[G3.a1] Cynosurus cristatus-Anthoxanthum odoratumAgrostis capillaris-Hypochaeris radicata-Trifolium repens grassland (70)

*[G3.a2] Coprosma ciliata parviflora complex/ Anthoxanthum odoratum-Holcus lanatus-Hypochaeris radicata-Trifolium repens-Crepis capillaris grassland (38)

[G4.a1] Lolium perenne-Holcus lanatus-Anthoxanthum odoratum-Dactylis glomerata-Trifolium repensHypochaeris radicata grassland (59) [G4.a2] Lolium perenne-Cynosurus cristatus-Holcus lanatus-Trifolium repens-Hypochaeris radicata grassland (70)

[G4.a3] Lolium perenne-Cynosurus cristatus-Holcus lanatus-Anthoxanthum odoratum-Trifolium repens Hypochaeris radicata grassland (71)

*[G4.a4] Dactylis glomerata-Holcus lanatus-Trifolium repens-Anthoxanthum odoratum-Cynosurus cristatusHypochaeris radicata grassland (57)

[G.a1] Vulpia bromoides-Aira caryophyllea-Austrostipa nodosa-Hypochaeris glabra-Rumex acetosella grassland association (37)

[G5.a1] Carex gaudichaudiana-Agrostis capillarisAnthoxanthum odoratum-Carex sinclairii-Holcus lanatus sedgeland (59)

[G5.a2] Poa pratensis-Agrostis capillaris-Carex

sinclairi-Phleum pratense grassland (46)

[R1.a1] Leptospermum scoparium/Empodisma minus- 


\begin{tabular}{|c|c|c|c|c|}
\hline Alliance & Distribution & $\begin{array}{l}\text { Elevational } \\
\text { range }(\mathrm{m})\end{array}$ & $\begin{array}{l}\text { Mean } \\
\text { percentage } \\
\text { exotic }\end{array}$ & Component associations \\
\hline Baumea rubiginosa rushland (81) & Stewart & & & $\begin{array}{l}\text { Gleichenia spp.-Baumea rubiginosa rushland (54) } \\
\text { [R1.a2] Empodisma minus-Gleichenia species rushland (18) }\end{array}$ \\
\hline $\begin{array}{l}\text { Coastal sand and gravel } \\
\text { [H1] Selliera radicans-Leptinella dioica- }\end{array}$ & NI, SI & $0-40$ & $13 \%$ & [H1.a1] Selliera radicans-Leptinella dioica herbfield (34) \\
\hline
\end{tabular}

Samolus repens herbfield (56)

Inland deposits

melanocaulon-Trifolium repens stonefield (220)
[StF1] Poa lindsayi-Raoulia hookeri-Epilobium SI

$300-1110 \quad 34 \%$

[StF2] Rosa rubiginosa/Trifolium arvensePilosella officinarium-Rumex acetosella stonefield (94)

\section{Alpine (not tall tussocklands)}

[G6] Poa colensoi/Chionochloa oreophilaCelmisia sessilifloraCelmisia haastii grassland (78)

[GF1] Poa colensoi/Luzula pumila-Raoulia hectorii gravelfield (80)

[GF2] Raoulia grandiflora-Veronica pulvinaris- SI Anisotome imbricata-Dracophyllum pronum gravelfield (70)

[H2] Celmisia spectabilis-Poa colensoi/ Anisotome aromatica-Euphrasia cuneata herbfield (79)

No corresponding alliance

\section{BUSH, HEATH, SCRUB AND FERNLAND}

\section{Temperate bush}

[BrF1] Fuchsia excorticata-Melicytus ramiflorus/Coprosma rotundifolia/Polystichum vestitum broadleaved forest ${ }^{1}(38)$

No corresponding alliance

\section{Low alpine shrub-heath}

No corresponding alliance

\section{Kānuka-mānuka heath}

$\left[\mathrm{S}^{2}\right]$ Leptospermum scoparium/Schoenus

brevifolius-[Gleichenia spp.] shrubland (67)

No corresponding alliance

NI $\quad 10-330 \quad 8 \%$

SI $\quad 380-810 \quad 73 \%$

$$
\text { SI }
$$

$1370-2070 \quad 1 \%$

$1110-1580 \quad 0 \%$

$1370-1640 \quad 0 \%$

$820-1730 \quad 3 \%$

$40-610 \quad 21 \%$

SI $\quad 40-610 \quad 21 \%$

(1)

[StF1.a1] Poa lindsayi-Agrostis capillaris-Raoulia haastii-Raoulia australis-Trifolium repensMuehlenbeckia axillaris stonefield (73) [StF1.a2] Poa lindsayi-Raoulia haastii-Raoulia hookeriEpilobium melanocaulon stonefield (72)

[StF1.a3] Poa lindsayi-Raoulia haastii-Raoulia hookeriEpilobium melanocaulon stonefield (53)

[StF2.a1] Rosa rubiginosa/Muehlenbeckia axillarisTrifolium arvense-Pilosella officinarium-Rumex acetosella stonefield (37)

[StF2.a2] Trifolium arvense-Pilosella officinariumArenaria serpyllifolia-Rumex acetosella stonefield (33)

[G6.a1] Poa colensoi/Chionochloa oreophila-Celmisia haastii-Celmisia sessiliflora grassland (50)

[GF1.a1] Poa colensoi/Luzula pumila-Raoulia hectoriiColobanthus buchananii gravelfield (70)

[GF2.a1] Raoulia grandiflora-Veronica pulvinarisAnisotome imbricata-Dracophyllum pronum-Gentianella luteoalba gravelfield (66)

[H2.a1] Celmisia spectabilis-Poa colensoi/ Wahlenbergia pygmaea-Gaultheria depressa-Euphrasia cuneata herbfield (39)

[H2.a2] Celmisia spectabilis-Poa colensoi/ Anisotome aromatica-Dracophyllum recurvum-Gentianella bellidifolia-Euphrasia cuneata herbfield (38)

[RL.a1] Raoulia youngii-Agrostis subulata-Colobanthus buchananii rockland association (12)

[BrF1.a1] Fuchsia excorticata-Melicytus ramiflorus/ Coprosma rotundifolia/Polystichum vestitum broadleaved forest (21)

[BrF.a1] Metrosideros umbellata/Dracophyllum longifolium-Coprosma foetidissima-Brachyglottis rotundifolia broadleaved forest association (16)

[S.a4] Chionochloa flavescens-Dracophyllum uniflorumPodocarpus nivalis-Celmisia coriacea-Myrsine nummularia shrubland association (31)

[S8.a1] Leptospermum scoparium/Gleichenia spp.Baumea teretifolia shrubland (39)

[S8.a2] Leptospermum scoparium-Hakea sericea/ Schoenus brevifolius shrubland (28)

[S.a5] Leptospermum scoparium/Phormium tenaxCoprosma ciliata parviflora complex-Coprosma propinqua-Blechnum novae-zelandiae shrubland association (14)

[S.a6] Leptospermum scoparium/Dracophyllum politumPentachondra pumila-Zotovia thomsonii-Carpha alpinaAstelia linearis shrubland association (27)

SI, South Island; NI, North Island; Stewart, Stewart Island

${ }^{1}$ Follows physiognomic typology described by Wiser et al. (2011)

${ }^{2}$ Numbering starts at 8, building on Wiser et al. (2011) and Wiser \& De Cáceres (2013): http://www.landcareresearch.co.nz/publications/factsheets/ woody-types 


\section{Tussocklands}

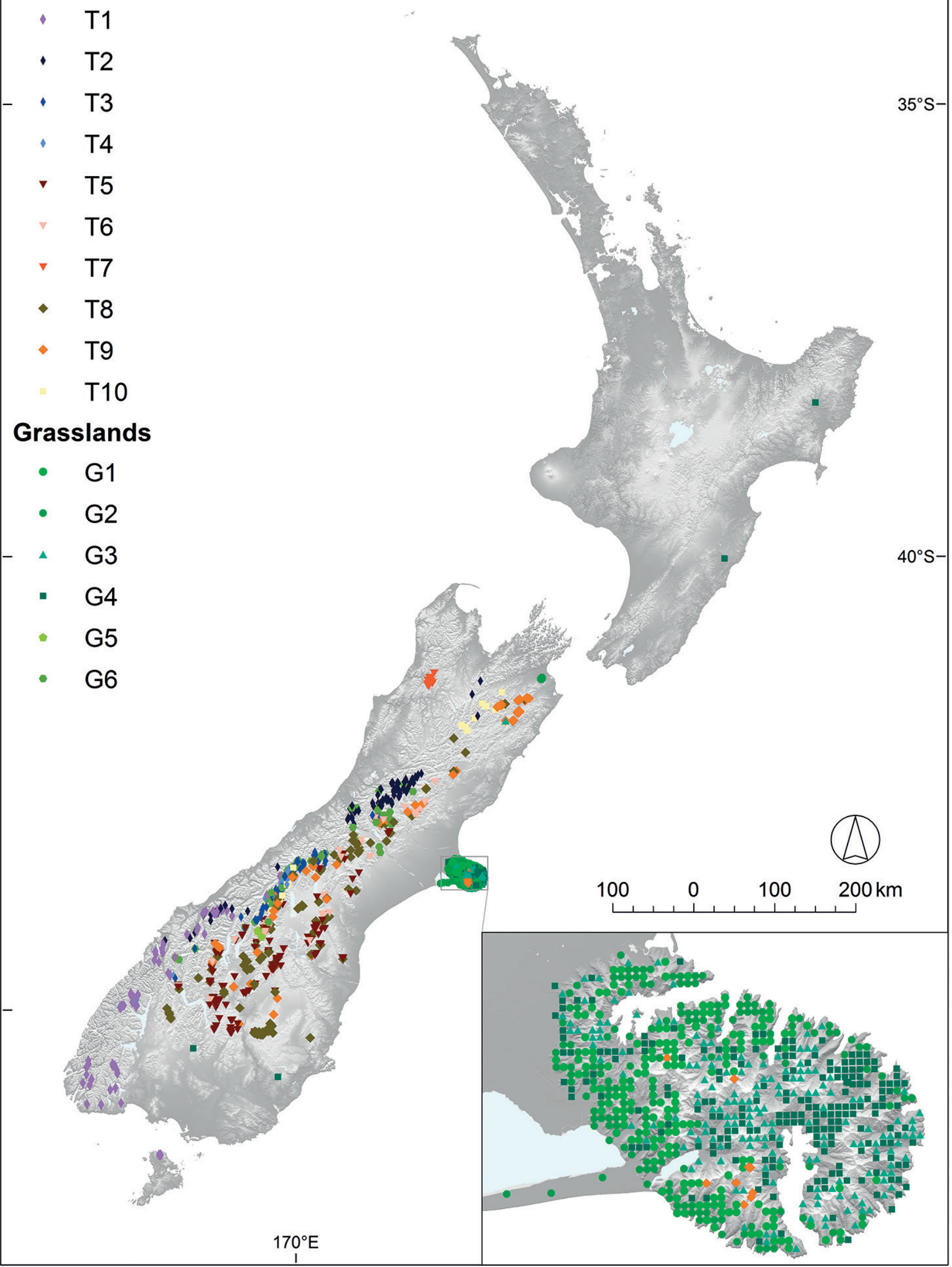

Figure 2. Plot locations for alliances that are tussocklands or other grasslands. 


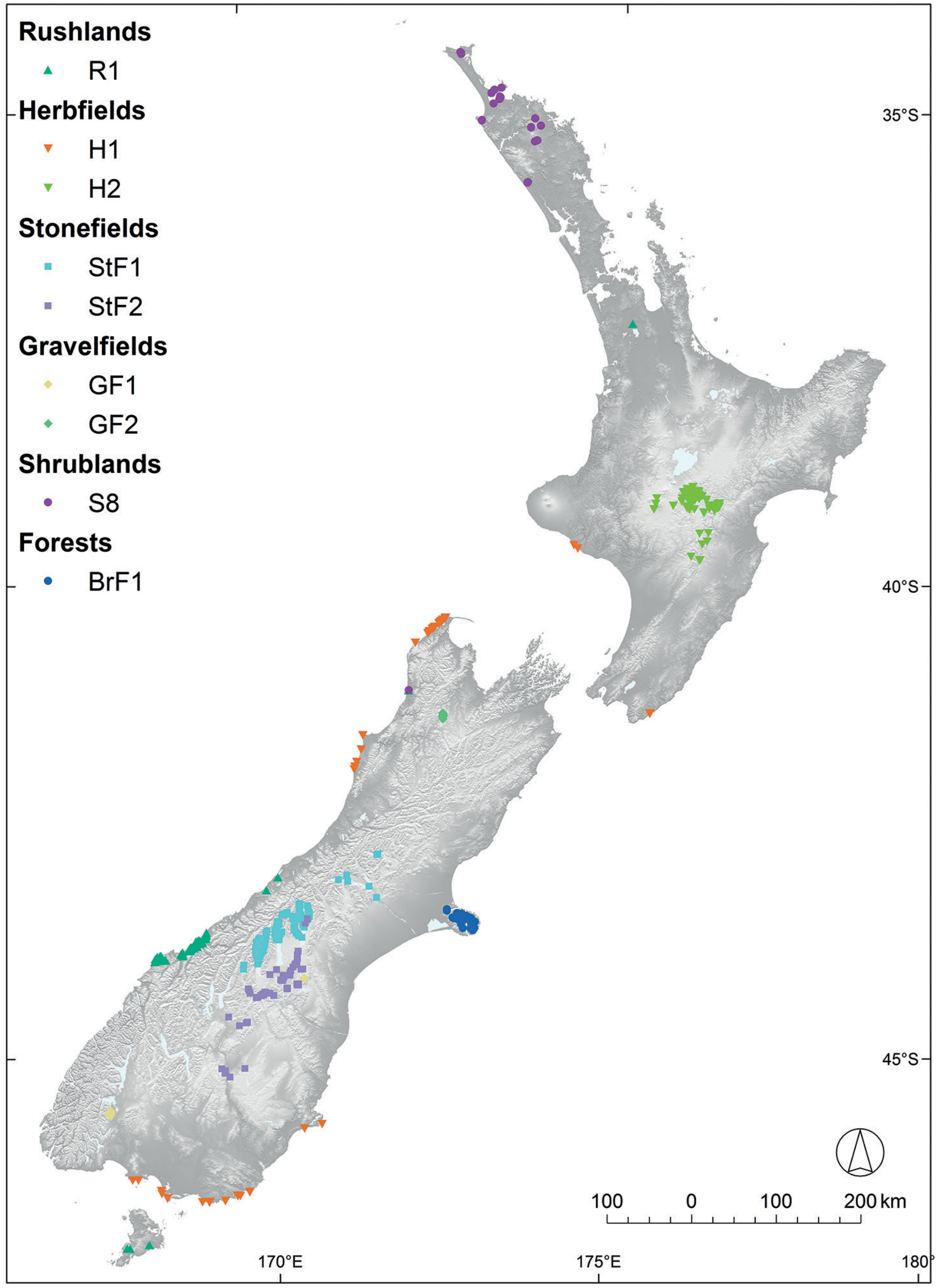

Figure 3. Plot locations for alliances that are gravelfields, herbfields, rushlands, shrublands or stonefields. 
The vegetation types

\section{GRASSLAND AND HERBFIELD}

\section{Subalpine-subnival snow tussock}

[T1] Chionochloa crassiuscula-Schoenus pauciflorus-Poa colensoi/Astelia linearis tussockland

This predominantly low alpine to alpine alliance is from west of the Main Divide southwards from Westland National Park and extends south to Stewart Island (Table 1, Fig. 2). Frequent species include Coprosma perpusilla and Lycopodium fastigiatum. This alliance encompasses the Chionochloa crassiuscula-dominated types described from northern Fiordland (Rose \& Platt 1987), Wapiti Lake, Fiordland (Rose et al. 1988) and Westland (Wardle 1977), which tend to occupy less fertile and more poorly drained sites than nearby C. pallens-dominated types.

[T2] Chionochloa pallens/Poa colensoi/Anisotome aromaticaGaultheria depressa tussockland

This low alpine to alpine alliance has a disjunct distribution, occurring either in areas north of Lewis Pass and in the Richmond Range, or near or west of the Main Divide from the Hope Pass to Mount Whitcombe and south of Mt Cook to northern Fiordland (Table 1, Fig. 2). On wetter sites the tussocks Chionochloa crassiuscula and Schoenus pauciflorus are frequent. Frequent species include Coprosma perpusilla, Celmisia discolor and Lycopodium fastigiatum. This alliance includes the Chionochloa pallens alliances of Wraight (1966) and Evans (1970) and the open Chionochloa pallens/turf vegetation type of Wardle (1977). Four associations were identified (Table 1), with one occurring north of Lewis Pass (T2.a1) and the other three occurring to the south. The northern association has the highest mean elevation (1600 $\mathrm{m})$. Here Chionochloa pallens and Poa colensoi are reduced in importance whereas C. australis (absent south of Arthur's Pass) increases (cf. C. australis types described by Bell (1973) and Williams (1991)). The other three associations differ either by elevation or slope steepness. Of the two lower elevation associations $(\bar{x}$ elevation $=1320$ and $1350 \mathrm{~m}$, respectively) the first one (T2.a2) has gentler slopes $\left(\bar{x}\right.$ slope $\left.=21^{\circ}\right)$, higher constancy of Chionochloa crassiuscula, and Poa kirkii is often present; the steeper one $\left(\mathrm{T} 2 . \mathrm{a} 3 ; \bar{x}\right.$ slope $\left.=31^{\circ}\right)$ has Geranium microphyllum, Blechnum penna-marina and Chionochloa flavescens, which are absent from the other three. The last association $(\mathrm{T} 2 . \mathrm{a} 4 ; \bar{x}$ elevation $=1420 \mathrm{~m})$ is the only one of the four with Kelleria dieffenbachii and Chionochloa oreophila.

[T3] Chionochloa pallens/Poa colensoi-Celmisia lyalliiChionochloa crassiuscula tussockland

This low alpine to alpine alliance is from Arthur's Pass to Mt Aspiring National Park (Table 1, Fig. 2). Two associations were identified (Table 1); T3.a1 occurs at higher elevations $(\bar{x}=1610 \mathrm{~m})$ and Chionochloa crassiuscula, Celmisia haastii and Raoulia grandiflora are more frequent; whereas in T3.a2 (elevation $=1390 \mathrm{~m}$ ) Schoenus pauciflorus, Lycopodium fastigiatum and Anisotome aromatica are more frequent. This alliance encompasses the 'Chionochloa pallens-Chionochloa crassiuscula grasslands' and elements of the ' $C$. pallens grasslands' of Wilson (1976) and most of the variation described for 'upland grassland' in the Upper Waitaki River catchment by Jane (1988).
[T4] Chionochloa pallens/Poa colensoi-Celmisia petrieiSchoenuspauciflorus/Wahlenbergiaalbomarginata tussockland

This low alpine to alpine alliance has a similar range to the previous [T3] alliance (Table 1, Fig. 2), but sites tend to be at lower elevations and slopes are steeper $\left(\bar{x}\right.$ slope $=31^{\circ}$, range $\left.=5-48^{\circ}\right)$. Sites tend to face east and south-east. This alliance shares dominant species with the T3 alliance but is distinguished by the reduced constancy of Chionochloa crassiuscula, Celmisia haastii and Celmisia lyallii, the increased constancy of Celmisia petriei, Schoenus pauciflorus, Wahlenbergia albomarginata and Dracophyllum uniflorum. Frequent species include Lycopodium fastigiatum, Anaphalioides bellidioides, Coprosma perpusilla and Gaultheria depressa. On average, 4\% of the species on a plot are exotic. This alliance encompasses the alpine 'Poa colensoi grassland' and elements of the 'Chionochloa pallens grasslands' of Wilson (1976) and much of the variation in the 'mid-ribbed snow tussock grasslands' of Jane (1988).

[T5] Chionochloa rigida/Poa colensoi-Festuca novaezelandiae/Hypochaeris radicata tussockland

This subalpine to alpine alliance is from the South Island in areas east of the Main Divide, from Porter's Pass to Central Otago (Table 1, Fig. 2). Frequent indigenous species include Luzula rufa, Viola cunninghamii, Raoulia subsericea, Wahlenbergia albomarginata, and Leucopogon fraseri. On average 19\% of the species on a plot are exotic with the most frequent being Rumex acetosella. Occasionally Chionochloa rigida or Festuca novae-zelandiae can be absent. This alliance corresponds to the Chionochloa rigida grassland of Wilson (1976) and encompasses much of the variation in C. rigida grassland described by Jane (1988). Three associations were identified (Table 1). The first, T5.a1, was from the northern range of the alliance and is where Pilosella officinarum is most abundant. The remaining two are from the southern part of the alliance range and separate along an elevational gradient. Chionochloa rigida and Anthoxanthum odoratum occur only in the lower $(\bar{x}$ elevation $=1120 \mathrm{~m})$ association $($ T5.a2), which is confined primarily to the subalpine zone. In the higher association (T5. a3, $\bar{x}$ elevation $=1460 \mathrm{~m})$, Festuca novae-zelandiae occurs in only $37 \%$ of plots, whereas Agrostis muelleriana, which is absent from the other associations, is always present.

[T6] Chionochloa macra-Poa colensoi/Celmisia lyallii[Luzula rufa] tussockland

This low alpine to subnival alliance is in areas from Lake Sumner to northern Fiordland (Table 1, Fig. 2). On average, $8 \%$ of the species on a plot are exotic. This alliance corresponds to the Chionochloa ' $Q$ 'grassland of Connor and Macrae (1969). For areas south of the Rakaia River, Connor and Macrae (1969), Wardle (1991) and Mark (1993) describe C. macradominated vegetation as occupying the transition between C. rigida-dominated types and low, open alpine vegetation, whereas north of the Rakaia River, C. rigida is absent so C. macra prevails.

\section{Cool temperate-low alpine tall red/copper tussock}

[T7] Chionochloa rubra/Schoenus pauciflorus-Celmisia coriacea-Coprosma cheesemanii tussockland

This subalpine to low alpine alliance is from only Kahurangi National Park in the South Island (Table 1, Fig. 2). Slopes tend to be gentler than those in the other grassland alliances 
$\left(\bar{x}\right.$ slope $=10^{\circ}$, range $\left.0-40^{\circ}\right)$. Frequent species include Microseris scapigera, Poa colensoi and Lobelia angulata. Most sites are either moderately or poorly drained, with the occurrence of species such as Schoenus pauciflorus and Microseris scapigera and the less frequent occurrence of Empodisma minus, Carex sinclairii, Carpha alpina, and Veronica pauciramosa corresponding with the more poorly drained sites. On average, $7 \%$ of the species on a plot are exotic; the most frequent ( $60 \%$ of the plots) being Hypochaeris radicata. This alliance conforms to the Chionochloa rubra/C. flavescens association, the most frequent of the six grassland types described from the Matiri and Owen ranges by Rose (1985).

[T.a1] Chionochloa rubra/Schoenus pauciflorus-Holcus lanatus-Anthoxanthum odoratum tussockland association (no corresponding alliance)

This cool temperate (elevation 40-850 m) association is from east of the Main Divide, primarily in the area now designated as Haketere Conservation Park, and also in scattered locations on the Southland Plains. Sites tend to be flat to very gently sloping. Frequent indigenous species include Bulbinella angustifolia. On average, $45 \%$ of the species on a plot are exotic; Trifolium repens is frequent. This association is congruent with the Canterbury Red-Tussock grassland of Connor (1965) and the Chionochloa rubra grassland of Connor and Macrae (1969).

\section{Cool temperate-low alpine short tussock}

[T8] Festuca novae-zelandiae-Anthoxanthum odoratum-Poa colensoi/Leucopogon fraseri tussockland

This cool temperate to low alpine alliance is from Southern Marlborough (Awatere River region) to Otago (Table 1, Fig. 2). Frequent indigenous species include Luzula rufa, Wahlenbergia albomarginata and Pimelea oreophila. On average, $28 \%$ of the species on a plot are exotic; frequent species are Hypochaeris radicata, Pilosella officinarum and Rumex acetosella. The domination of short tussock grasslands in Canterbury and parts of Marlborough by Festuca novae-zelandiae and Poa colensoi is well documented (e.g. Connor \& Macrae 1969; Wardle 1991), and this alliance encompasses the Fescue-Tussock grassland of Connor (1965). Five component associations were identified (Table 1) and are described in a north to south sequence. The most northerly (T8.a1), occurring only north of the Rakaia River, is the only association with Ozothamnus leptophyllus ( $85 \%$ constancy). This association also has the highest mean elevation $(\bar{x}=1190 \mathrm{~m})$, the steepest slopes $\left(\bar{x}\right.$ slope $\left.=27^{\circ}\right)$ and generally westerly aspects. The most widespread association $(\mathrm{T} 8 . \mathrm{a} 2 ; \bar{x}$ elevation $=770 \mathrm{~m})$ has the highest constancy $(78 \%)$ of Holcus lanatus. The inland association from Porter's Pass to Lake Hawea (T8.a3) occurs at similar elevations and has the highest level of exotic invasion $(\bar{x}$ percentage exotic $=60)$. The subalpine to low alpine association (T8.a4; $\bar{x}$ elevation $=1090 \mathrm{~m}$ ), extending from Mt Cook to Queenstown, has the highest constancy of Raoulia subsericea and Hieracium lepidulum. The southernmost and most geographically restricted association (T8.a5) was found only at Mt Hutt and in the Manorburn Ecological District, at a mean elevation of $910 \mathrm{~m}$. Sites tend to be flat or with gentle slopes $(\bar{x}$ slope $=$ $4^{\circ}$ ). This is the only association of the alliance having Raoulia subulata and Chionochloa rubra.
[T9] Festuca novae-zelandiae/Anthoxanthum odoratumTrifolium repens-Hypochaeris radicata grassland

This cool temperate to low alpine alliance is from the South Island east of Main Divide from Southern Marlborough (Awatere Valley area) to Central Otago and including Banks Peninsula (Table 1, Fig. 2). Poa cita and Wahlenbergia albomarginata are frequent indigenous species. On average, $46 \%$ of the species on a plot are exotic, with Rumex acetosella, Holcus lanatus and Crepis capillaris frequent. This alliance corresponds to the Festuca novae-zelandiae-Anthoxanthum odoratum-Cassinia leptophylla vegetation type of Rose et al. (1998). Three component associations were defined (Table 1). The first (T9.a1) is widely distributed and occurs on more northerly aspects, gentler slopes, and lower elevations, is more invaded and is the only one of the three with Festuca rubra. The other two associations are distinguished from each other geographically - the first (T9.a2) is confined to Southern Marlborough whereas the second (T9.a3) also occurs in South Canterbury - and floristically, with Uncinia divaricata, Anthosachne scabra and Epilobium alsinoides being present and frequent in the first but not the second.

[T10] Poa colensoi-Rytidosperma setifolium-Festuca matthewsii/Wahlenbergia albomarginata tussockland

This subalpine to alpine alliance is from the Richmond RangeWairau River region and in the Upper Waitaki River catchment (Table 1, Fig. 2). On average, $19 \%$ of the species on a plot are exotic, the most frequent being Hypochaeris radicata. This alliance has strong similarities to the Festuca matthewsii/ Notodanthonia setifolia association of Wraight (1963) and the blue tussock/fescue/sweet vernal type of Jane (1988).

\section{Adventive-dominated grasslands}

[G1] Poa cita-Dactylis glomerata/Anthoxanthum odoratumTrifolium repens grassland

This cool temperate alliance is from only Banks Peninsula (Table 1, Fig. 2). No indigenous species other than Poa cita are found on more than $50 \%$ of the plots and this is the only alliance defined with $P$. cita as a dominant. On average, $70 \%$ of the species on a plot are exotic. Frequent species include Holcus lanatus, Hypochaeris radicata, Lolium perenne, Cynosurus cristatus, Vicia sativa, Trifolium dubium, Cerastium fontanum, Anthosachne scabra and Crepis capillaris.

[G2] Lolium perenne-Bromus hordeaceus-Vulpia bromoidesTrifolium glomeratum grassland

This warm to cool temperate alliance is primarily from Banks Peninsula but also from the Wither Hills in Marlborough (Table 1, Fig. 2). Sites tend to face west. On average $81 \%$ of the species on a plot are exotic. Frequent species include Hypochaeris radicata and Trifolium dubium. The two component associations differ in their level of invasion $(\bar{x}$ percentage exotic $=76$ and 90 for G2.a1 and G2.a2, respectively). The presence of Poa cita, Anthosachne scabra, and Anthoxanthum odoratum in G2.a1 distinguish it from G2.a2.

[G3] Cynosurus cristatus-Trifolium repens-Anthoxanthum odoratum-Hypochaeris radicata grassland

This cool temperate alliance is primarily from Banks Peninsula, but also from the Awatere Valley in Marlborough (Table 1, Fig. 2 ). The only indigenous species that is consistently present is Rytidosperma clavatum (constancy $=71 \%$ ). On average, 
$83 \%$ of the species on a plot are exotic. Frequent species include Holcus lanatus, Lolium perenne, Dactylis glomerata, Crepis capillaris and Agrostis capillaris. The two component associations segregate along an elevational gradient $(\bar{x}=240$ and $590 \mathrm{~m}$ for G3.al and G3.a2, respectively), with G3.a1 being more invaded $(\bar{x}$ percentage exotic $=84 \%$ vs $45 \%)$. G3.a2 is distinguished by the presence of Helichrysumfilicaule, species of the Coprosma ciliata/parviflora complex and C.rhamnoides.

[G4] Lolium perenne-Holcus lanatus-Trifolium repensHypochaeris radicata grassland

This warm to cool temperate alliance is primarily from Banks Peninsula ( $98 \%$ of the plots), but also from scattered locations on the North Island and South Island (Table 1, Fig. 2). On average, $93 \%$ of the species on a plot are exotic; no indigenous species consistently occur. Frequent species include Dactylis glomerata, Anthoxanthum odoratum and Cynosurus cristatus. Four component associations were identified (Table 1), but no clear distinctions in environment or geography were apparent.

[G.a1] Vulpia bromoides-Aira caryophyllea-Austrostipa nodosa-Hypochaeris glabra-Rumex acetosella grassland association (no corresponding alliance)

This cool temperate association was from south-western Banks Peninsula at very low elevations $(2-10 \mathrm{~m})$. Frequent indigenous species include Rytidosperma caespitosum and Convolvulus waitaha. On average, $85 \%$ of the species on a plot are exotic, with frequent species including Trifolium dubium, T. striatum, T. glomeratum and Silene gallica.

\section{Wetlands}

\section{Eutrophic swamps and marshes}

[G5] Agrostis capillaris-Carex sinclairii-Poa pratensisHolcus lanatus grassland

This cool temperate alliance is primarily from Birchwood wetland in the Ahuriri Valley in the Mackenzie Basin (Table 1, Fig. 2). Parts of this wetland are intact, whereas other parts have been drained (Newham \& Quirin 2007). Frequent species include Juncus effusus. On average, $72 \%$ of the species on a plot are exotic. The two component associations differ primarily in their invasion level. In the first (G5.a1; $\bar{x}$ percentage exotic $=$ $64 \%$ ), the indigenous wetland species Carex gaudichaudiana and Schoenus pauciflorus are more frequent, whereas in the second $(\mathrm{G} 5 . \mathrm{a} 2 ; \bar{x}$ percentage exotic $=81 \%)$ Phleum pratense is more frequent.

\section{Oligotrophic lowland mires}

[R1] Empodisma minus-Gleichenia spp.-Baumea rubiginosa rushland

This cool temperate alliance is from widely scattered locations on the North Island, South Island and Stewart Island. On the North Island, it was sampled in Whangamarino (south of Auckland). South Island locations are on the West Coast, particularly in the vicinity of Kahurangi National Park and South Westland (Table 1, Fig. 3). Sites are usually flat (slope $=0^{\circ}$, range $=0-2^{\circ}$ ). Frequent species include Leptospermum scoparium. This alliance conforms to the pakihi described by Mark and Smith (1975), the Empodisma minus/Gleichenia dicarpa bog with prominent shrubs of Wilson (1987), and is similar to the pakihi of Wardle (1977) and the Mānukal Dracophyllum/wire rush rushland and wire rush-tangle fern-
Baumea rushland of Norton and Leathwick (1990), where $D$. longifolium is replaced by D. palustre. There are two component associations: R1.a1 is distinguished by the presence of Baumea rubiginosa and is concentrated in South Westland whereas R1.a2 has a scattered distribution.

\section{Coastal sand and gravel}

\section{[H1] Selliera radicans-Leptinella dioica-Samolus repens} herbfield

This alliance is restricted to widely scattered, exposed coastal sites on the south and west coasts of the North Island and the north-western, south-eastern and southern coasts of the South Island (Table 1, Fig. 3). It includes most plots in the coastal turf communities described by Rogers and Wiser(2010) except for the compositionally distinct andesitic tephra turfs in the Taranaki region. Vegetation types conforming to this alliance have also been described from Stewart Island (Wilson 1987).

\section{Inland deposits}

\section{[StF1] Poa lindsayi-Raoulia hookeri-Epilobium melanocaulon-Trifolium repens stonefield}

This cool temperate to subalpine alliance is from braided riverbeds from Lewis Pass to Mount Cook National Park and the Upper Waitaki River catchment (Table 1, Fig. 3). Frequent species include Epilobium microphyllum and Muehlenbeckia axillaris. On average, $34 \%$ of the species on a plot are exotic. This alliance conforms to the new riverbed type (Wilson 1976) and the Raoulia haastii-Epilobium melanocaulon stonefield of Woolmore (2011). Three largely sympatric associations (StF1.a1, StF1.a2, StF1.a3) were identified that reflect an elevational sequence, with mean elevations of 640, 730 and $860 \mathrm{~m}$, respectively. Agrostis capillaris, Holcus lanatus, Rumex acetosella, Pilosella officinarum, Anthoxanthum odoratum, Raoulia australis and Colobanthus strictus decrease in importance with increased elevation whereas Epilobium melanocaulon and Helichrysum depressum increase in importance.

[StF2] Rosa rubiginosa/Trifolium arvense-Pilosella officinarium-Rumex acetosella stonefield

This cool temperate to subalpine alliance is from braided riverbeds from the Upper Waitaki Basin to Lake Wakatipu (Table 1, Fig. 3). In contrast to the previous alliance, which occurs on the upper reaches of braided rivers, this is more common on the lower reaches. On average, $73 \%$ of the species on a plot are exotic. This alliance corresponds to the Rosa rubiginosa/Muehlenbeckia axillaris herb stonefield of Woolmore (2011). Two sympatric associations were defined that separate on an elevational gradient. The lower elevation association (StF2.a1; $\bar{x}=480 \mathrm{~m}$ ) is distinguished by the presence of Muehlenbeckia axillaris and Festuca rubra, whereas the higher one (StF2.a2; $\bar{x}=675 \mathrm{~m})$ is distinguished by the presence of Arenaria serpyllifolia and Poa pratensis.

\section{Alpine (not tall tussocklands)}

[G6] Poa colensoi/Chionochloa oreophila-Celmisia sessiliflora-Celmisia haastii grassland

This low alpine to subnival alliance (mean elevation highest of any alliance; Table 1) is from Lake Sumner to Mt Aspiring 
National Park (Fig. 2). Typically, 25\% of the ground is bare or rocky, but this can be as high as $90 \%$. Frequent species include Raoulia grandiflora and Phyllachne colensoi. This alliance encompasses the Chionochloa oreophila grasslands described by Wraight (1960), Archer (1973) and Wilson (1976), the snow hollow grass type of Jane (1988), and the Chionochloa oreophila/Poa colensoi grassland of Wardle (1977).

\section{[GF1]Poa colensoi/Luzula pumila-Raouliahectorii gravelfield}

This low alpine to alpine alliance is largely restricted to $\mathrm{Mt}$ Titiroa in northern Southland, on the eastern edge of Fiordland National Park (Table 1, Fig. 5). Slopes are relatively gentle; $\left(\bar{x}\right.$ slope $=15^{\circ}$, range $\left.2-32^{\circ}\right)$ and often south-facing. Mt Titiroa and the Lookout Range (see next alliance) are distinctive in supporting the two extensive granite gravel fields in New Zealand, an ecosystem type that is considered naturally uncommon (Williams et al. 2007; Richardson et al. 2012). Short-statured plants are scattered across the substrate; mean vegetation cover percentage is only $9 \%$ and vegetation is rarely more than $3 \mathrm{~cm}$ high. Frequent species include Colobanthus buchananii and Hectorella caespitosa.

[GF2] Raoulia grandiflora-Veronica pulvinaris-Anisotome imbricata-Dracophyllum pronum gravelfield

This low alpine alliance is restricted to the Lookout Range, Kahurangi National Park (Table 1, Fig. 3). Slopes are gentle $\left(\bar{x}\right.$ slope $=8^{\circ}$, range $\left.=1-18^{\circ}\right)$. Mean vegetation cover percentage is $16 \%$ and vegetation is rarely more than $3 \mathrm{~cm}$ high. Frequently occurring species include Luzula colensoi, Gentianella luteoalba, and Poa colensoi. No exotics are present.

[H2] Celmisia spectabilis-Poa colensoi/Anisotome aromaticaEuphrasia cuneata herbfield

This subalpine to low alpine alliance is from the North Island, on the Volcanic Plateau and in the nearby Kaimanawa, Kaweka and Ruahine ranges (Table 1, Fig. 3). Frequent species include Wahlenbergia pygmaea, Gaultheria depressa, Dracophyllum recurvum, Lycopodium fastigiatum, Gentianella bellidifolia, Coprosma perpusilla and Celmisia gracilenta. This alliance has similarities to the Chionochloa pallens, Poa colensoi subassociation of Cuddihy (1977) and the Celmisia/Senecio/ Gaultheria low shrubland and various Dracophyllum/ Notodanthonia types of Scott (1977). Two associations were defined that separate by elevation. The lower elevation association $(\mathrm{H} 2 . \mathrm{a} 1 ; \bar{x}=1260 \mathrm{~m})$ is distinguished by the presence of Leucopogon fraseri and Hypochaeris radicata. The higher elevation association ( $\mathrm{H} 2 . \mathrm{a} 2 ; \bar{x}=1470 \mathrm{~m}$ ) is distinguished by Chionochloa pallens and Forstera tenella and has no exotics.

[RL.a1] Raoulia youngii-Agrostis subulata-Colobanthus buchananii rockland association (no corresponding alliance)

This subnival association (elevation $1850-2290 \mathrm{~m}$ ) is from Mt Cook National Park on steep slopes $\left(\bar{x}\right.$ slope $=40^{\circ}$, range $\left.=15-60^{\circ}\right)$ with much bare ground $(\bar{x}=97 \%)$. Sites are species poor; the only other species recorded from this association (but all occurring in fewer than $60 \%$ of the plots) were Luzula pumila, Poanovae-zelandiae, Anisotomeflexuosa and Veronica haastii. Exotic species are absent. This association conforms to the lower nival rock type of Wilson (1976).

\section{BUSH, HEATH, SCRUB AND FERNLAND}

\section{Temperate bush}

[BrF1] Fuchsia excorticata-Melicytus ramiflorus/Coprosma rotundifolia/Polystichum vestitum broadleaved forest

This cool temperate alliance is from the South Island on Banks Peninsula (Table 1, Fig. 3). Slopes are generally steeper than those predominating in most other alliances $\left(\bar{x}\right.$ slope $=32^{\circ}$, range $=10-75^{\circ}$ ) and tend to face east through to south. Mean top height averages $6 \mathrm{~m}$ and ranges from 2 to $13 \mathrm{~m}$. On average, $21 \%$ of the species are exotic.

[BrF.a1] Metrosideros umbellata/Dracophyllum longifoliumCoprosmafoetidissima-Brachyglottis rotundifolia broadleaved forest association (no corresponding alliance)

This cool temperate association (elevation $0-410 \mathrm{~m}$ ) is from Stewart Island. Frequent species include Blechnum procerum and Microsorum pustulatum. Mean top height averages $8 \mathrm{~m}$ and ranges from 4 to $15 \mathrm{~m}$. This association encompasses much of the variation in Stewart Island's 'inland low forest and scrub with prominent Olearia colensoi and/or Dacrydium on hillslopes' described by Wilson (1987).

\section{Low alpine shrub-heath}

[S.a4] Chionochloa flavescens-Dracophyllum uniflorumPodocarpus nivalis-Celmisia coriacea-Myrsine nummularia shrubland association (no corresponding alliance)

This low alpine association (elevation 900-1380 $\mathrm{m}$ ) is from Mt Cook National Park, South Island. Frequent species include Veronica subalpina, Gaultheria crassa and Coprosma pseudocuneata. This association corresponds to the Chionochloa flavescens-Dracophyllum uniflorum shrubland of Wilson (1976).

\section{Kānuka-mānuka heath}

[S8] Leptospermum scoparium/Schoenus brevifolius[Gleichenia spp.] shrubland

This warm temperate alliance is from the North Island, north of Auckland, with one South Island site in Kahurangi National Park (Table 1, Fig. 3). Sites can be flat to gently sloping $\left(\bar{x}=3^{\circ}\right.$, range $=0-19^{\circ}$ ). Mean top height (i.e. height of the dominant vegetation) ranges from $20 \mathrm{~cm}$ to $2 \mathrm{~m}$. On average, $8 \%$ of the species on a plot are exotic. This alliance encompasses the northern gumland vegetation types 'LeptospermumGleichenia shrubland' and 'Leptospermum shrubland' described by Clarkson et al. (2011), which we recognise as distinct associations (Table 1). Sites are on the moderately to well-drained end of the spectrum for gumland vegetation more generally, with the two associations segregating such that the former is on the moderately drained sites and the latter is on better drained sites.

Two associations dominated by Leptospermum scoparium were defined that do not fit into any alliances defined here or by Wiser and De Cáceres (2013):

[S.a5] Leptospermum scoparium/Phormium tenaxCoprosma ciliata-parviflora complex-Coprosma propinquaBlechnum novae-zelandiae shrubland

This cool temperate association is found only in South Westland, South Island, from just above sea level to $80 \mathrm{~m}$ on moderately drained flat terraces. Vegetation is short $(\bar{x}$ mean 
top height $=0.5 \mathrm{~m}$, range $=0.05-1.5 \mathrm{~m}$ ). This association conforms to the Phormium flaxland of Duncan et al. (1990).

[S.a6] Leptospermum scoparium/Dracophyllum politumPentachondra pumila-Zotovia thomsonii-Carpha alpinaAstelia linearis shrubland

This cool temperate association (elevation $70-650 \mathrm{~m}$ ) is from Stewart Island. Mean top height ranges from 1 to $5 \mathrm{~m}$. Frequent species include Donatia novae-zelandiae, Oreobolus impar and $O$. pectinatus. This alliance encompasses most of the variability described by Wilson (1987) in subalpine boggy, grassland, cushionfield and cushion shrubland.

\section{Do unclassified plots sample specific environments or unstructured vegetation?}

Across all datasets, outlier plots occurred on sites with higher mean annual air temperature $\left(\right.$ median $=8.1^{\circ} \mathrm{C}$ vs $7.5^{\circ} \mathrm{C}, W=$ $3229517, P<0.0001$ ), higher mean minimum air temperature of coldest month (median $=-1.6^{\circ} \mathrm{C}$ vs $-2^{\circ} \mathrm{C}, W=3297217$, $P<0.0001$ ), and higher mean annual solar radiation (median $=13.6$ vs $13.7 \mathrm{MJ} \mathrm{m}^{-2}$ day, $W=3922748, P<0.0001$ ) than classified plots, as we expected, but with lower October vapour pressure deficit (median $=0.28$ vs $0.34 \mathrm{kPa}, W=3889881$, $P<0.0001$ ) and lower percentage of exotics on a plot (median $=10 \%$ vs $20 \%, W=4299583, P<0.0001$ ), in contrast to our expectatons.

Within datasets, outlier plots tended to occur at lower elevations, although this was not statistically significant (on average, outlier plots are $145 \mathrm{~m}$ lower than classified plots, $\mathrm{t}=$ -1.12 , d.f $=41, P=0.26)$. There were no differences between assigned and outlier plots for species richness $(\mathrm{t}=-0.07$, $P=0.94)$ or percentage of exotics $(\mathrm{t}=0.83, P=0.41)$.

\section{Discussion}

Our quantitative classification depicts some of the well-known, geographic, and elevational differences in composition among widely distributed short and tall tussock grasslands of the South Island, described by Wardle (1991) and Mark (1993). The classification reflects the importance of Chionochloa pallens, $C$. crassiuscula and $C$. oreophila dominated vegetation in western, wetter regions compared with $C$. rigida and $C$. macra dominance in the drier eastern regions, and the domination of eastern South Island short tussock grasslands by Festuca novae-zelandiae and Poa colensoi. Compositional differences related to elevation are captured, such as, within Chionochloa dominated communities, the decreased importance of species other than C. crassiuscula, C. macra, and C. oreophila with ascension into higher alpine and subnival zones and, among exotic-dominated grasslands, the increase in exotic dominance with decreasing elevation.

We also demonstrate the pronounced compositional distinctiveness of four naturally uncommon ecosystems coastal turfs, northern gumlands, granite sand plains, and braided riverbeds - for which there are relatively large datasets. It is notable that within two of these (granite sand plains, braided riverbeds) there is sufficient compositional variation to allow different alliances to be defined, despite their narrow distribution. The classification also demonstrates that other localities having distinctive vegetation composition can be successfully differentiated if there are enough plots (e.g. the alliance at Birchwood wetland).
Our dataset lacked sufficient plot data to depict other well-known distinctions in non-forest ecosystems. Few nongrassland alpine vegetation types, no North Island Chionochloa rubra dominated type, only two wetland types, and only one coastal type were defined. Chionochloa rubra occurred in only 42 of 270 plot records from the North Island. Of these, 17 plots were assigned to $\mathrm{H} 2$ Celmisia spectabilis-Poa colensoi/ Anisotome aromatica-Euphrasia cuneata herbfield and C. rubra had relatively low abundance, 12 were transitional, and 13 were designated as outliers. Wetland data are relatively under-represented in the National Vegetation Survey Databank, with much of these data being archived separately (Clarkson et al. 2003). Our dataset did include datasets encompassing coastal turfs and locations on Banks Peninsula and Stewart Island, but it was not extensive enough to capture the variation in the myriad types of coastal vegetation.

Much of the plot data that has been collected from nonforest vegetation are not readily available. There are numerous published community-level floristic summaries of non-forest vegetation based on plot data (e.g. Hubbard \& Wilson 1988; Wardle 1991) or studies that describe underpinning plot data (e.g. Wilson \& Meurk 2011), but the primary data were never archived and in some instances may have been lost. There are also numerous instances where individual plot records are published, but not digitised (e.g. Archer \& Cutler 1983; Treskonova 1991) and where hard-copies of data have been archived, but the data are yet to be digitised in a standardised format (e.g. numerous Protected Natural Areas surveys, the height-frequency transects described by Dickinson et al.(1992) and Scott (1977), and plots in the GLORIAnetwork (Mark etal. 2006)). Inclusion of these records would considerably extend the vegetation types described to incorporate more Chionochloa tussock grassland types, snowbanks and cushionfields. Once these historical data, and any newly collected data, become available in digital form, they can be accommodated by our methodological approach.

Amuch higher degree offine-scale compositional variation has previously been described based on datasets we included, for example, from the Matiri and Owen ranges (Rose 1985), Mount Cook (Wilson 1976), Stewart Island (Wilson 1987), and Banks Peninsula basaltic outcrops (Wiser \& Buxton 2009). This is a consequence of the internal heterogeneity among the unclassified plots being too great to allow a vegetation type to be defined with our criteria of minimum numbers of plots at the alliance and association level and our threshold for internal heterogeneity, based on our choices of values for the distance parameter. If national-scale, formal definition of this variation is required, this could be overcome by more intensive plot data collection in these areas.

Our approach of using the abundance measure of relative ranks to allow datasets collected using disparate methodologies to be combined proved reasonably robust on our demonstration dataset. Further, at the national scale, plots having data collected in different ways were included in the same alliances and associations and allowed us to define recognisable vegetation types nationally. This indicates that the data collection method did not have undue influence on the classification outcome. To be even more inclusive, we could have reduced the data to presence-absence (Wilson 2012), which can sometimes increase the strengths of correlations between ordination axis scores and environment. However, for this classification we felt this approach would place undue emphasis on infrequent species and would not allow the pronounced differences in tussock grasslands in relative dominance of the major Chionochloa 
species to influence the definition of types. Although we have demonstrated that abundance values can be simplified to allow disparate datasets to be combined, we still advocate adoption of consistent data collection methods if a goal is to underpin vegetation classification. In New Zealand, application of the 'Recce' method to fixed-area plots is the most consistent with the major plot data collection methods worldwide used to underpin classifications (Peet \& Roberts 2013). This is also consistent with earlier studies in New Zealand non-forest vegetation (e.g. Barker 1953; Connor 1961, 1964; Moore et al. 1976). It is important to note, however, that other sampling methods may be more appropriate for assessing long-term changes in composition and structure in non-forest vegetation (reviewed by Wiser \& Rose 1997).

It is notable that the percentages of plots designated as outliers (32\% at alliance, $48 \%$ at association) are so much higher than in the comparable analysis of New Zealand woody vegetation by Wiser and De Cáceres $(2013 ; 12 \%$ at alliance, $18 \%$ at association). There are several potential explanations. First, the total beta-diversity across New Zealand non-forest vegetation is likely to be substantially higher than for woody vegetation because of both the higher total species numbers and the longer environmental gradients being traversed; at the same time there are fewer readily available datasets suitable for classification. Second, much non-forest vegetation may be inherently 'noisy' in composition. Moore (1976) concurred with the observation of Braun-Blanquet $(1929,1964)$ that not all collections of plants can or should be described as a vegetation type, and in the New Zealand context this was particularly so where exotic species predominate and 'accidental' combinations of species may occur. Hubbard and Wilson (1988) and Wilson et al. (1989) concluded that lack of community structure in grasslands resulting from deforestation in the inland eastern South Island represented a non-equilibrium situation that could be explained by either incomplete recovery from disturbance or by the likelihood that exotic invaders had not yet fully expanded to their potential ranges. Our finding that outlier plots are actually less invaded, however, suggests that this cannot be the only explanation. Third, distinctive non-forest vegetation may be represented by too few plots to adequately define them as distinct vegetation types, either because they are 'spasmodic relict occurrences' (Wilson et al. 1989) or are undersampled. Indeed, that $92 \%$ of the plots designated as outliers are $100 \%$ native implies that this is the most likely explanation.

Although we have confidence in our defined alliances and associations and have gained understanding of why plots may be designated as outliers, it is unsatisfying that such a high proportion of the plots in our dataset remain unclassified. Leaving high proportions of a dataset unclassified in New Zealand classifications is not new (cf. McKelvey 1984), but it does remove the information they contain from any management or conservation decisions based on the classification. Our approach to excluding transitional and outlier plots from the set of plots used to define vegetation types optimises the compositional distinctiveness of vegetation types, but compromises inclusiveness, or in other words, it emphasises the nodal, or central tendencies of the types, but de-emphasises the boundaries between types. The application of fuzzy classification and Noise Clustering in vegetation classification is still relatively new. The methodological choices that best balance the emphases on noda versus boundaries and allow those plots that would be recognised intuitively by ecologists as outliers to be so designated need further exploration. Varying the distance parameter $\delta$ influences both the typological resolution of the classification and the number of plots assigned to the outlier class. Choosing a membership threshold of $>0.5$ to assign plots to both clusters and the Noise class is intuitively reasonable as this rule ensures that the distinction between membership in the Noise class or clusters is unambiguous. However, it is not the only option. A higher threshold could be chosen for membership to the Noise cluster, with plots otherwise being assigned to the cluster to which they have highest membership, but this could result in ambiguous membership. A second risk in having so many plots designated as outliers is that unique components of the compositional variation, particularly vegetation types that are rare on the landscape and potentially sampled from only a few plots, may be omitted from the classification. Development of approaches to allow 'provisional' alliances or associations to be defined would be useful to address this problem.

\section{Conclusions}

We have outlined the advantage of quantitatively-derived plot-based classifications and demonstrated the application of a framework that allowed us to initiate a classification of New Zealand's non-forest vegetation, despite the lack of available data for all vegetation types and the heterogeneity in field measurement protocols. The described types have known locations of occurrence and well-defined compositional properties. In the future, indicator value analyses (e.g. De Cáceres et al. 2012), which quantify the fidelity of species in relation to the plots of a vegetation type, could be used to facilitate identification of types in the field. That these types have known locations, and are often associated with permanent plots (usually frequency transects), enables them to be used as baselines to assess compositional change and, where permanent plots have been measured in the past, to understand how they have changed to date. Finally, this classification can be continuously refined as new data become available, both to define new types and to increase the thematic resolution within defined alliances and associations.

\section{Acknowledgements}

SKW and FJT were supported by the New Zealand Department of Conservation and Core funding for Crown Research Institutes from the New Zealand Ministry of Business, Innovation and Employment's Science and Innovation Group. MDC was supported by a Beatriu de Pinós postdoctoral grant (2009 BP-B 00342) from the Catalan Agency for Management of University and Research Grants and a 'Ramón y Cajal' fellowship (RYC-2012-11109) granted by the Spanish Ministry of Education and Science (MEC) and the International Mobility Fund administered by the Royal Society of New Zealand (contract SPN 10-13). We acknowledge the use of data drawn from the National Vegetation Survey Database and thank all those who wore out their boots collecting the original data. We thank Robbie Price for GIS support and Hugh Wilson, Peter Williams, Matt McGlone, Rob Allen, Dave Roberts, David Keith, Joerg Ewald, Peter Bellingham, Alan Mark and Tom Wentworth for helpful discussions and comments on earlier versions. 


\section{References}

Allen RB 1992. Recce: an inventory method for describing New Zealand vegetation. FRI Bulletin 181. Christchurch, Forest Research Institute.

Archer AC 1973. Plant succession in relation to a sequence of hydromorphic soils formed on glacio-fluvial sediments in the alpine zone of the Ben Ohau Range, New Zealand. New Zealand Journal of Botany 11: 331-348.

ArcherAC, Cutler EJB 1983. Pedogenesis and vegetation trends in the alpine and upper subalpine zones of the northeast Ben Ohau Range, New Zealand. 2. Plant communities and plant succession. New Zealand Journal of Science 26: $151-171$

Atkinson IAE 1962. Semi quantitative measurements of canopy composition as a basis for mapping vegetation. Proceedings of the New Zealand Ecological Society 9: 1-8.

Atkinson IAE 1985. Derivation of vegetation mapping units for an ecological survey of Tongariro National Park North Island, New Zealand. New Zealand Journal of Botany 23: 361-378.

Barker AP 1953. An ecological study of tussock grassland, Hunters Hills, South Canterbury. DSIR Bulletin 107.58 p.

Bell CJE 1973. Mountain soils and vegetation in the Owen Range, Nelson: 1. The soils. New Zealand Journal of Botany 11: 49-72.

Braun-Blanquet J 1929, 1964. Pflanzensoziologie, Grundzüge der Vegetationskunde. 1. Aufl. Springer, Berlin X +330 p; 3. Aufl. Springer, Wien-New York. XIV + 845 p.

Cieraad E, McGlone MS 2014. Thermal environment of New Zealand's gradual and abrupt treeline ecotones. New Zealand Journal of Ecology 38: 12-25.

Cieraad E, McGlone MS, Huntley B 2014. Southern Hemisphere temperate tree lines are not climatically depressed. Journal of Biogeography 41:1456-1466.

Clarkson BR, Sorrell BK, Reeves PN, Champion PD, Partridge TR, Clarkson BD 2003. Handbook for monitoring wetland condition. Coordinated monitoring of New Zealand wetlands. Wellington, Ministry for the Environment.

Clarkson BR, Smale MC, Williams PA, Wiser SK, Buxton RP 2011. Vegetation ecology of gumland heaths in northern New Zealand. New Zealand Journal of Ecology 35:96-113.

Cockayne L 1928. The vegetation of New Zealand. In: Engler A, Drude O eds Die Vegetation der Erde. 2. Liebzig, Engelmann.

Cockayne L, Calder JW 1932. The present vegetation of Arthur's Pass (New Zealand) as compared with that of thirty-four years ago. Journal of Ecology 20: 270-283.

Connor HE 1961. A tall-tussock grassland community in New Zealand. New Zealand Journal of Science 4: 825-835.

Connor HE 1964. Tussock grassland communities in the Mackenzie Country, South Island, New Zealand. New Zealand Journal of Botany 2: 325-351.

Connor HE 1965. Tussock grasslands in the middle Rakaia Valley, Canterbury, New Zealand. New Zealand Journal of Botany 3: 261-276.

Connor HE, MacRaeAH 1969. Montane and subalpine tussock grasslands in Canterbury. In: Knox GA ed. The natural history of Canterbury. 2nd edn. Wellington, Reed. Pp. 167-204.

Cuddihy MJ 1977. Forests, grasslands and animals of the southern Ruahine Range. Protection Forestry Report 151. Ilam, Protection Forestry Division, New Zealand Forest Service.
Dave RN 1991. Characterization and detection of noise in clustering. Pattern Recognition Letters 12: 657-664.

De Cáceres M, Wiser SK 2012. Towards consistency in vegetation classification. Journal of Vegetation Science 23: 387-393.

De Cáceres M, Font X, Oliva F 2010. The management of numerical vegetation classification with fuzzy clustering methods. Journal of Vegetation Science 21: 1138-1151.

De Cáceres M, Legendre P, Wiser SK, Brotons L 2012. Using species combinations in indicator value analyses. Methods in Ecology and Evolution 3: 973-982.

De Cáceres M, Chytrý M, Agrillo E, Attorre F, Botta-Dukát Z, Capelo J, Czúcz B, Dengler J, Ewald J, Faber-Langendoen D, Enrico F, Franklin S, Gavilán R, Gillet F, Jansen F, Jiménez-Alfaro B, Krestov P, Landucci F, Lengyel A, Loidi J, Mucina L, Peet R, Roberts D, Roleček J, Schaminée J, Schmidtlein S, Theurillat J, Tichý L, Walker D, Wildi O, Willner W, Wiser SK. 2015. A comparative framework for broad-scale plot-based vegetation classification. Applied Vegetation Science. doi: 10.1111/avsc. 12179.

Dickinson KJM, Mark AF, Lee WG 1992. Long-term monitoring of non-forest communities for biological conservation. New Zealand Journal of Botany 30: 163-179

Duncan RP, Norton DA, Woolmore CB 1990. The lowland vegetation pattern, south Westland, New Zealand 2. Ohinemaka forest. New Zealand Journal of Botany 28: 131-140.

Duncan RP, Webster RJ, Jensen CA 2001. Declining plant species richness in the tussock grasslands of Otago and Canterbury, South Island, New Zealand. New Zealand Journal of Ecology 25(2): 35-47.

Evans GR 1970. The alpine grasslands of the Taramakau River catchment. Protection Forestry Report 61. Rangiora, Protection Forestry Branch, New Zealand Forest Service.

Faber-Langendoen D, Keeler-Wolf T, Meidinger D, Tart D, Hoagland B, Josse C, Navarro G, Ponomarenko S, Saucier J-P, Weakley A, Comer P 2014. EcoVeg: a new approach to vegetation description and classification. Ecological Monographs 84: 533-561.

Hubbard JC, Wilson JB 1988. A survey of the lowland vegetation of the Upper Clutha District of Otago, New Zealand. New Zealand Journal of Botany 26: 21-35.

Hurst JM, Allen RB 2007. The Recce method for describing New Zealand vegetation - field protocols. Lincoln, Manaaki Whenua - Landcare Research.

Jane GT 1988. Waitaki grasslands and forest survey, 1985/6. Canterbury Region Survey Report 16. Christchurch, Canterbury Regional Office, Department of Conservation.

Jennings MD, Faber-Langendoen D, Loucks OL, Peet RK, Roberts D 2009. Standards for associations and alliances of the US National Vegetation Classification. Ecological Monographs 79: 173-199.

Johnson PN 1992. The sand dune and beach vegetation inventory of New Zealand. II. South Island and Stewart Island. DSIR Land Resources Scientific Report 16.278 p.

Leathwick J, Whitehead D 2001. Soil and atmospheric water deficits and the distribution of New Zealand's indigenous tree species. Functional Ecology 15(2): 233-242.

Leathwick J, Morgan F, Wilson G, Rutledge D, McLeod M, Johnston K 2002. Land environments of New Zealand: a technical guide. Auckland, Ministry for the Environment.

Mark AF 1978. Mount Aspiring National Park vegetation survey: permanent photographic points for following vegetation changes. Tussock Grasslands and Mountain 
Lands Institute Review 37: 38-45.

Mark AF 1993. Indigenous grasslands of New Zealand. In: Coupland RT ed. Ecosystems of the World 8B: Natural grasslands: Eastern Hemisphere and résumé. Amsterdam, Elsevier. Pp. 361-410.

Mark AF, McLennan B 2005. The conservation status of New Zealand's indigenous grasslands. New Zealand Journal of Botany 43: 245-270.

Mark AF, Dickinson KJ, Maegli T, Halloy SR 2006. Two GLORIA long-term alpine monitoring sites established in New Zealand as part of a global network. Journal of the Royal Society of New Zealand 36: 111-128.

Mark AF, Porter S, Piggott JJ, Michel P, Maeglp T, Dickinson KJ 2008. Altitudinal patterns of vegetation, flora, life forms, and environments in the alpine zone of the Fiord Ecological Region, New Zealand. New Zealand Journal of Botany 46: 205-237.

Mark AF, Smith PMF 1975. A lowland vegetation sequence in South Westland: pakihi bog to mixed beech-podocarp forest Part 1: The principal strata. Proceedings of the New Zealand Ecological Society 22: 76-92.

McGlone M, Wood J, Bartlein PJ 2012. Environmental Change in the Temperate Forested Regions. In: Matthews JA, Bartlein PJ, Briffa KR, Dawson AG, De Vernal A, Denham T, Fritz SC, Oldfield F eds The Sage handbook of environmental change. Sage, CA. Pp. 188-214.

McKelvey PJ 1984. Provisional classification of South Island virgin indigenous forests. New Zealand Journal of Forestry Science 14(2): 151-178.

Meurk CD 1995. Evergreen broadleaved forests of New Zealand and their bioclimatic definition. In: Box EO, Peet RK, Masuzawa T, Yamada I eds Vegetation science in forestry. The Hague, Netherlands, Kluwer Academic. Pp. 151-197.

Moore LB, Molloy BPJ, Irvine RE 1976. The changing vegetation of Molesworth Station, New Zealand, 1944 to 1971. DSIR Bulletin 217.

Mucina L 1997. Classification of vegetation: Past, present and future. Journal of Vegetation Science 8: 751-760.

Newcombe RG 1998. Interval estimation for the difference between independent proportions: comparison of eleven methods. Statistics in Medicine 17: 873-890.

Newham R, Quirin C 2007. Enhancing the conservation value of the Birchwood Wetland. Wildlife Management Report 203. Dunedin, Department of Zoology, University of Otago.

Newsome PFJ 1987. The vegetative cover of New Zealand. Wellington, National Water and Soil Conservation Authority.

Newsome P, Pairman D 2012. LCDB v3.0 - Land cover database, version 3. Palmerston North, Landcare Research. http://lris.scinfo.org.nz/layers/tag/lcdb3/\#/layer/304-lcdbv30-land-cover-database-version-3/ (accessed October 2012).

Norton DA, Leathwick JR 1990. The lowland vegetation pattern, South Westland, New Zealand 1. Saltwater Ecological Area. New Zealand Journal of Botany 28: 41-51.

Orloci L 1967. An agglomerative method for classification of plant communities. The Journal of Ecology: 193-206.

Partridge TR 1992. The sand dune and beach vegetation inventory of New Zealand: 1. North Island. DSIR Land Resources Scientific Report 15.

Peet RK, Roberts DW 2013. Classification of natural and seminatural vegetation. In: van der Maarel E, Franklin J eds
Vegetation ecology. New York, Oxford University Press.

Podani J 2005. Multivariate exploratory analysis of ordinal data in ecology: pitfalls, problems and solutions. Journal of Vegetation Science 16(5): 497-510.

Richardson SJ, Williams PA, Mason NWH, Buxton RP, Courtney SP, Rance BD, Clarkson BR, Hoare RJB, St. John MG, Wiser SK 2012. Rare species drive local trait diversity in two geographically disjunct examples of a naturally rare alpine ecosystem in New Zealand. Journal of Vegetation Science 23: 626-639.

Rogers GM, Wiser SK 2010. Environment, composition, and conservation of coastal turfs of mainland New Zealand. New Zealand Journal of Botany 48: 1-14.

Rose AB 1985. The high-altitude grasslands. In: Davis MR, Orwin J eds Report on a survey of the proposed Wapiti Area, West Nelson. FRI Bulletin 84. Christchurch, Forest Research Institute. Pp. 110-124.

Rose AB, Platt KH 1987. Recovery of northern Fiordland alpine grasslands after reduction in the deer population. New Zealand Journal of Ecology 10: 23-33.

Rose AB, Harrison JBJ, Platt KH 1988. Alpine tussockland communities and vegetation-landform-soil relationships, Wapiti Lake, Fiordland, New Zealand. New Zealand Journal of Botany 26: 525-540.

Rose AB, Basher LR, Wiser SK, Platt KH, Lynn IH 1998. Factors predisposing short-tussock grasslands to Hieracium invasion in Marlborough, New Zealand. New Zealand Journal of Ecology 22: 121-140.

Scott D 1977. Plant ecology above timber line on Mt Ruapehu, North Island, New Zealand: I. Site factors and plant frequency. New Zealand Journal of Botany 15: 255-294.

Silvertsen 2009. Native vegetation interim type standard. Sydney, NSW, Department of Environment, Climate Change and Water.

Singers NJ, Rogers GM2014. Aclassification of New Zealand's terrestrial ecosystems. Science for Conservation 325.

Tichý L, Chytrý M, Botta-Dukát Z 2014. Semi-supervised classification of vegetation: preserving the good old units and searching for new ones. Journal of Vegetation Science 25: $1504-1512$.

Treskonova M 1991. Changes in the structure of tall tussock grasslands and infestations by species of Hieracium in the Mackenzie Country, New Zealand. New Zealand Journal of Ecology 15: 65-78.

Walker S, Lee WG 2002. Alluvial grasslands of Canterbury and Marlborough, eastern South Island, New Zealand: Vegetation patterns and long-term change. Journal of the Royal Society of New Zealand 32: 113-147.

Wardle P 1977. Plant communities of Westland National Park (New Zealand) and neighbouring lowland and coastal areas. New Zealand Journal of Botany 15: 323-398.

Wardle P 1991. Vegetation of New Zealand. Cambridge, Cambridge University Press.

Williams PA 1991. Subalpine and alpine vegetation of granite ranges in western Nelson, New Zealand. New Zealand Journal of Botany 29: 317-330.

Williams PA, Wiser S 2004. Determinants of regional and local patterns in the floras of braided riverbeds in New Zealand. Journal of Biogeography 31: 1355-1372.

Williams PA, Wiser SK, Clarkson B, Stanley M 2007. New Zealand's historically rare terrestrial ecosystems set in a physical and physiognomic framework. New Zealand Journal of Ecology 31: 119-128.

Wilson JB 2012. Species presence/absence sometimes 
represents a plant community as well as species abundances do, or better. Journal of Vegetation Science 23: 1013-1023.

Wilson JB, Meurk CD 2011. The control of community composition by distance, environment and history: a regional-scale study of the mountain grasslands of southern New Zealand. Journal of Biogeography 38: 2384-2396.

Wilson JB, Williams PA, Lee WG 1989. Vegetation composition and segregation in relation to the environment at low altitudes in the Upper Clutha Basin, New Zealand. New Zealand Journal of Ecology 12: 103-116.

Wilson HD 1976. Vegetation of Mount Cook National Park, New Zealand. National Parks Authority scientific series no. 1. Wellington, Department of Lands and Survey. 138 p.

Wilson HD 1987. Vegetation of Stewart Island, New Zealand: a supplement to the New Zealand Journal of Botany. Wellington, DSIR. $131 \mathrm{p}$.

Wiser SK, Buxton RP 2009. Montane outcrop vegetation of Banks Peninsula, South Island, New Zealand. New Zealand Journal of Ecology 33: 164-176.

Wiser SK, De Cáceres M 2013. Updating vegetation classifications: an example with New Zealand's woody vegetation. Journal of Vegetation Science 24: 80-93.

Wiser SK, Rose AB 1997. Two permanent plot methods for monitoring changes in grasslands: a field manual. Lincoln, Manaaki Whenua Press. 51 p.

Wiser SK, Bellingham PJ, Burrows L 2001. Managing biodiversity information: development of the National Vegetation Survey Databank. New Zealand Journal of Ecology 25(2): 1-17.

Editorial board member: Hannah Buckley

Received 19 December 2014; accepted 7 September 2015

\section{Supplementary Material}

Additional supporting information may be found in the online version of this article:

Appendix S1. List of datasets and number of plots used from each.

Appendix S2. Evaluation statistics of the classification results at the level of alliance and association.

Appendix S3. Assignment of associations into alliances.

Appendix S4. Final assignment of plot records used for the new classification based on rank data.

Appendix S5. Synoptic table of distribution and abundance of species across 25 alliances.

The New Zealand Journal of Ecology provides online supporting information supplied by the authors where this may assist readers. Such materials are peer-reviewed and copy-edited but any issues relating to this information (other than missing files) should be addressed to the authors.
Wiser SK, Drake DR, Burrows LE, Sykes WR 2002. The potential for long-term persistence of forest fragments on Tongatapu, a large island in western Polynesia. Journal of Biogeography 29(5-6): 767-787.

Wiser SK, Buxton RP, Clarkson BR, Richardson SJ, Rogers GM, Smale MC, Williams PA 2010. Climate, landscape, and microenvironments interact to determine plant composition in naturally discrete gravel beach communities. Journal of Vegetation Science 21: 657-671.

Wiser SK, Hurst JM, Allen RB, Wright EF 2011. New Zealand's forest and shrubland communities: a classification based on a nationally representative plot network. Applied Vegetation Science 14: 506-523.

Woolmore CB 2011. The vegetation of braided rivers in the Upper Waitaki basin: South Canterbury, New Zealand. Canterbury series 0211. Christchurch, Canterbury Conservancy, Department of Conservation. 67 p.

Wraight MJ 1960. The alpine grasslands of the Hokitika river catchment, Westland. New Zealand Journal of Science 3: 306-332.

Wraight MJ 1963. The alpine and upper montane grasslands of the Wairau River catchment, Marlborough. New Zealand Journal of Botany 1: 351-376.

Wraight MJ 1966. The alpine and upper montane grasslands of the Waimakiriri River catchment. Protection Forestry Report 29. Rangiora, Forestry Protection Branch, Forest Research Institute. 